\title{
ADDITIONAL REPORT ON CALANOID COPEPODS FROM THE IZU REGION -PART 3-A. EUAETIDEUS, AETIDEOPSIS, CHIRIDIUS, GAIDIUS, AND GAETANUS-
}

\author{
$\operatorname{AUTHOR}(\mathrm{S}):$ \\ Tanaka, Otohiko; Omori, Makoto
}

\section{CITATION:}

Tanaka, Otohiko ...[et al]. ADDITIONAL REPORT ON CALANOID COPEPODS FROM THE IZU REGION -PART 3-A. EUAETIDEUS, AETIDEOPSIS, CHIRIDIUS, GAIDIUS, AND GAETANUSPUBLICATIONS OF THE SETO MARINE BIOLOGICAL LABORATORY 1970, 18(2): 109-141

\section{ISSUE DATE:}

1970-10-20

URL:

http://hdl.handle.net/2433/175625

RIGHT: 


\title{
ADDITIONAL REPORT ON CALANOID COPEPODS FROM THE IZU REGION \\ PART 3-A. EUAETIDEUS, AETIDEOPSIS, CHIRIDIUS, GAIDIUS, AND GAETANUS
}

\author{
Otohiko TANAKA ${ }^{1)}$ and MAKoto OMORI ${ }^{2)}$
}

With 11 Text-figures

In the family Aetideidae the copepods belonging to Euchirella and Pseudochirella have been reported in the previous paper (TANAKA and OMORI, 1969). The present report deals with taxonomy of the remaining 32 spesies in 10 genera obtained from Sagami and Suruga Bays and their southern waters (Table 1). And in this first half (A) of the present report Part 3, 24 species in 5 genera are explained. The sampling data of 29 samples, taken in 1964 and 1965, have been given in Part 1 of the report. All specimens have been deposited in the Ocean Research Institute, University of Tokyo.

Table 1. List of species
1. Euatideus aculus (FARRAN)
17. Gaetanus armiger GIESBRECHT
2. E. bradyi (A. ScotT)
18. G. brevicornis EsTERLY
3. Aetideopsis cristata TANAKA
19. G. kruppii GresbrechT
4. A. multiserrata (WolfEnden)
20. G. latifrons SARS
5. A. rosirata SARs
21. G. miles Giesbrecht
6. Chiridius armalus (BoEcK)
22. G. minispinus TANAKA
7. C. gracilis FARRAN
23. G. minor FARRAN
8. C. molestus TANAKA
24. G. pileatus FARRAN
9. C. poppei Giesbrecht
25. Chirundina streetsii GIESBRECHT
10. Gaidius brevispinus (SARs)
26. Undeuchaeta magna TANAKA
11. G. pungens GiesbreatT
27. U. major GIEsBrechT
12. G. robustus (SARs)
28. U. plumosa (LUBBock)
13. G. tenuispinus (SARs)
29. Pseudeuchaeta brevicauda SARS
14. G. variabilis BroDskY
30. Valdiviella insignis FARRAN
15. G. species
31. V. origarthra STEUER
16. Gaetanus ?antarcticus WoLfENDEN
32. Chiridiella macrodactyla SARS

1) 60 Sangenchaya-machi, Setagaya-ku, Tokyo

2) Ocean Research Institute, University of Tokyo, Nakano, Tokyo

Publ. Seto Mar. Biol. Lab., XVIII (2), 109-141, 1970. (Article 9) 
Among the specimens examined, Chiridius armatus, Gaetanus antarcticus, Gaetanus brevicornis, Gaetanus latifrons, and Gaetanus minispinus have not previously been recorded from Japanese waters.

Regarding Gaidius, the genus seems to be composed of 12 species: G. affinis SARs, G. brevicaudatus SARs, G. brevispinus (SARs), G. inermis (SARs), G. intermedius Wolfenden, G. robustus (SARs), G. brevirostris Brodsky, G. columbiae PARK, G. minutus Sars, G. pungens Giesbrecht, G. tenuispinus (SArs), and G. variabilis Brodsky. The first 6 species each have a 3-segmented exopod in the 1 st leg; the remaining species have an incompletely 2 -segmented exopod. Except $G$. brevicaudatus, the species belonging to the first group have a lamella on the anterior margin of the lst basal segment of the maxilliped. The species of the latter group lack this lamella. TANAKA (1957a) reported $G$. brevispinus, G. minutus, G. tenuispinus, and $G$. moderatus from the Izu region. In addition, TANAKA and OMORI (1967) found G. robustus (as Pseudogaetanus robustus). Except for $G$. minutus, these species were obtained in the present collection. The examination of these specimens revealed that $G$. moderatus is identical with $G$. variabilis, and the male described as G. tenuispinus by TANAKa is the male of G. pungens. As pointed out by PARK (1967), G. minutus from the Izu region is $G$. columbiae.

The authors wish to express their appreciation to Professor R. Marumo of the Ocean Research Institute for his encouragement.

\section{EUAETIDEUS SARS, 1925}

Euaetideus acutus (FARRAN, 1929)

Aetideus acutus Farran, 1929, p. 228, fig. 5; Tanaka, 1957a, p. 36, fig. 25.

Euaetideus aculus (Farran).-Vervoort, 1957, p. 51, figs. 28-30; Brodsky, 1962, p. 119, fig. 22; PARK, 1968, p. 545, pl. 5, figs. 8-14.

Occurrence: Sta. 93-1, 1q; Sta. 97-2, 1; Sta. 115-1, 1q; Sta. 115-2, 1q; Sta. $117-1,1$ 우.

Distribution and size variation:

\begin{tabular}{|c|c|c|c|c|}
\hline \multirow[t]{2}{*}{ Author } & \multirow[t]{2}{*}{ Locality } & \multirow[t]{2}{*}{ Depth $(\mathrm{m})$} & \multicolumn{2}{|c|}{ Length (mm) } \\
\hline & & & 우 & $\hat{j}$ \\
\hline FARRAN, 1929 & South Atlantic & 0 & $1.68-1.80$ & - \\
\hline FARRAN, 1936 & Great Barrier Reef & 225 & $1.56-1.62$ & $1.23-1.30$ \\
\hline TANAKA, 1957a & Izu region & 0 & 1.66 & - \\
\hline VERVOORT, 1957 & Malay Archipelago & - & 1.70 & - \\
\hline BRODSKY, 1962 & Northwestern Pacific & 0 & $1.57-1.68$ & - \\
\hline GRICE, 1962 & Tropical Pacific & $61-146$ & $1.55-1.70$ & - \\
\hline PARK, 1968 & Central North Pacific & $0-140$ & $1.65-1.78$ & - \\
\hline Present record & Izu region & $0-620$ & $1.56-1.78$ & - \\
\hline
\end{tabular}




\section{Euaetideus bradyi (A. ScotT, 1909)}

Aetideus bradyi A. Scotт, 1909, p. 38, pl. 5, figs. 1-12; Tanaka, 1957a, p. 34, fig. 24.

Euaetideus bradyi (A. ScotT).-WILson, 1950, p. 202, pl. 7, figs. 70, 71; Vervoort, 1957, p. 48, figs. 20b, 21-23.

Occurrence: Sta. 114, 1 우.

Distribution and size variation:

Author

Locality

Depth $(\mathrm{m}) \quad$ Length (mm)

A. Sсотт, 1909

Wilson, 1950

TANAKA, 1957a

VERVOORT, 1957

Grice, 1962

Vervoort, 1963

Present record
Malay Archipelago

Off British Columbia

Izu region

East Indian Ocean

Tropical Pacific

Gulf of Guinea

Izu region

\begin{tabular}{llr} 
& \multicolumn{1}{c}{ } & \multicolumn{1}{c}{ क } \\
$0-700$ & 1.8 & - \\
$0-550$ & \multicolumn{1}{c}{-} & 1.50 \\
0 & 1.46 & - \\
- & 1.69 & - \\
$72-146$ & $1.60-1.70$ & - \\
$0-100$ & $1.38-1.67$ & - \\
$0-930$ & 1.50 & -
\end{tabular}

\section{AETIDEOPSIS SARS, 1903 \\ Aetideopsis cristata Tanaka, 1957}

Aetideopsis cristala TANAKA, 1957a, p. 42, fig. 28.

Occurrence: Sta. 93-2, 1 9 ; Sta. 108, 28, 1ふ.

Distribution and size variation:

Author

Locality

TANAKa, 1957a

Present record
Izu region

Izu region
Depth (m) Length (mm)

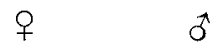

$\begin{array}{lll}0-1000 & 3.84 & 3.25\end{array}$

$0-1000 \quad 3.60-3.80 \quad 3.80$

\section{Aetideopsis multiserrata (Wolfenden, 1904)}

Faroella multiserrata Wolfenden, 1904, p. 117, pl. 9, figs. 26-28.

Aetideopsis multiserrata (Wolfenden).-SARs, 1925, p. 43, pl. 14, figs. 4-8; Tanaka, 1957a, p. 37, fig. 26.

Chiridius nasutus WrTH, 1915, p. 81, text-fig. 18, pl. 2, fig. 4.

Occurrence: Sta. 83, 4q; Sta. 84-2, 7q; Sta. 93-1, 1 ; Sta. 94, 2; Sta. 98, 1 ; Sta. 108, 2; Sta. 111-1, 1 ; Sta. 112, 1 क; Sta. 113, 1 \%; Sta. 114, 2o; Sta. 115-2, 1 우.

Remarks: In the present specimens the integument is finely granulated, as 
Vervoort (1951) observed in Aetideopsis minor Wolfenden. The specimen agrees quite well with the description by WIтH (1915) in the proportional length of the outer marginal spine of the 1st segment of the exopod of the 1st leg. The numbers of teeth on the terminal spine of the exopod of the 2 nd to 4 th legs are 30 to 40 , as WITH (1915) reported. The cutaneous pores are observed on the exopodal segments of the 2nd to 4 th legs.

Distribution and size variation:

\begin{tabular}{|c|c|c|c|c|}
\hline Author & Locality & Depth $(\mathrm{m})$ & Length ( 1 & \\
\hline & & & 우 & $\hat{0}$ \\
\hline WOLFENDEN, 1904 & North Atlantic & $366-1100$ & 3.54 & - \\
\hline WITH, 1915 & North Atlantic & $500-600$ & 2.88 & - \\
\hline SARS, 1925 & West of the Azores & $0-1200$ & 2.80 & - \\
\hline FARRAN, 1926 & Bay of Biscay & $915-2290$ & 2.64 & - \\
\hline Brodsky, 1950 & Central Arctic & $100-1400$ & $2.8-3.5$ & - \\
\hline Tanaka, 1957a & Izu region & $0-1000$ & 3.13 & 3.04 \\
\hline VERVOORT, 1963 & Gulf of Guinea & $0-100$ & 2.80 & - \\
\hline $\begin{array}{l}\text { Grige and } \\
\text { HuLSEMANN, } 1965\end{array}$ & Northeast Atlantic & $2000-3000$ & 2.20 & - \\
\hline Present record & Izu region & $0-520$ & $2.75-3.40$ & - \\
\hline
\end{tabular}

\section{Aetideopsis rostrata SARS, 1903}

(Fig. 1, a-g)

Aetideopsis rostrata SARs, 1903, p. 160, suppl. pls. 4, 5; WrTi, 1915, p. 86, text-fig. 22, pl. 2, fig. 6 . Aetideopsis divergens TANaKA, $1957 \mathrm{a}$, p. 40, fig. 27.

Occurrence: Sta. 93-1, 1 ; Sta. 93-2, 1 ㅇ.

Descriptive notes: Female, $3.14 \mathrm{~mm}$. The cephalothorax and abdomen are in the proportional lengths $73: 27$. The integument is finely granulated. The head is separated from the 1 st thoracic segment. The frontal margin of the head is produced when viewed from the dorsal. The rostrum is bifurcate; its rami are widely separated and very strong; they are directed downward and then upward. The lateral expansions of the last thoracic segment extend to the middle of the genital segment.

The abdominal segments and furca are in the following proportional lengths:

\begin{tabular}{lrrrrr} 
segment & $1-2$ & 3 & 4 & 5 & furca \\
\cline { 2 - 5 } & 19 & 14 & 12 & 18
\end{tabular}$=100$

The genital segment is produced moderately below; it is about as long as wide. The first 3 segments are fringed with fine teeth on the distal margin: the furca is 
1.5 times as long as wide.

The 1st antenna extends to the distal margin of the 3rd abdominal segment: the segments are in the following proportional lengths:

\begin{tabular}{lrrrrrrrrrrrrrr} 
segment & 1 & 2 & 3 & 4 & 5 & 6 & 7 & $8-9$ & 10 & 11 & 12 & 13 & 14 & 15 \\
\cline { 2 - 12 } & 57 & 26 & 26 & 26 & 29 & 29 & 65 & 26 & 26 & 26 & 35 & 39 & 42
\end{tabular}

\begin{tabular}{llllllllll}
16 & 17 & 18 & 19 & 20 & 21 & 22 & 23 & 24 & 25 \\
\hline 42 & 45 & 48 & 57 & 65 & 41 & 51 & 57 & 55 & $19=1000$
\end{tabular}

In the 2nd antenna the exopod is longer than the endopod: the endopod is
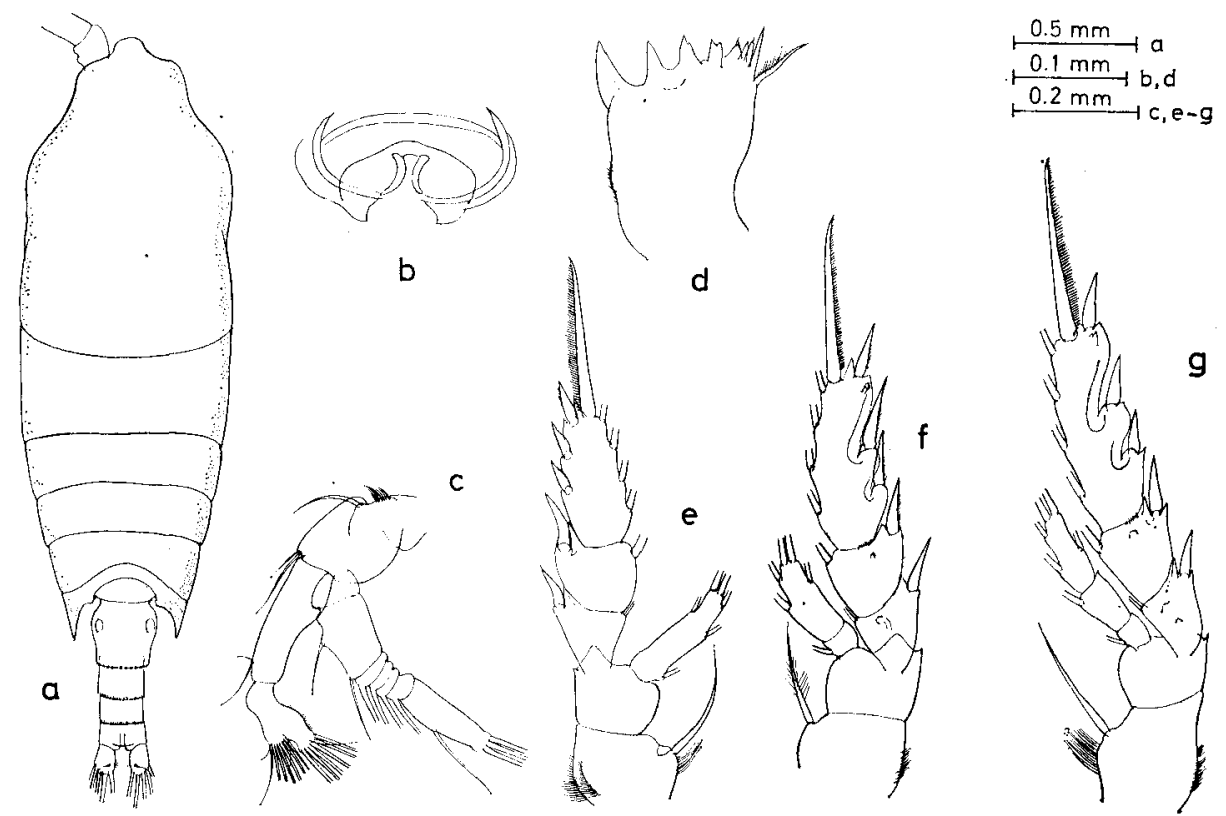

Fig. 1. Aetideopsis rostrata (SARs), female: a, whole body, dorsal view; b, genital area; c, 2nd antenna; d, cutting blade of mandible; e, lst leg; f, 2nd leg; g, 3rd leg.

furnished with 6 long setae and 1 small appendicular seta on the outer lobe and 9 setae on the inner lobe: the 2 nd segment of the exopod has 2 marginal setae. In the mandible the endopod is about half as long as the exopod; the 1st and 2nd segments of the endopod have 2 and 10 setae respectively; the cutting blade bears 8 teeth and a marginal spine. The 1st maxilla has the following number of setae on the various lobes: 9 on the outer lobe, 10 on the exopod, $6+3+4$ on the 3 rd to 1 st segments of the endopod, 5 on the 2 nd basal segment, 4 on the 3rd inner lobe, 4 on the 2 nd inner lobe, and 14 on the 1 st inner lobe. The 2 nd maxilla has 6 long setae on the endopod. In the maxilliped the 1st basal segment is shorter than the 2nd, 
and has a small seta on the 1st lobe.

The 1st leg has a 3-segmented exopod and 1-segmented endopod; the exopod is furnished with long and slender spines on the 1st to 3rd segments respectively; the spine on the 2nd segment reaches almost the middle of the 3rd segment. The 2nd leg has a 3-segmented exopod and 2-segmented endopod; the terminal spine of the exopod has about 55 teeth; a cutaneous pore is found on each segment of the exopod. The 3rd and 4th legs have 3-segmented exopods and endopods; the terminal spines of the exopod of these legs have 43 and 45 teeth respectively.

Remarks: Aetideopsis rostrata resembles $A$. minor Wolfenden or $A$. trichechus VERVOORT both in general appearance and in the structure of the mouthparts and swimming legs. However, it differs from $A$. minor in the shape of the rostrum which is more divergent than in A. minor. VERVOoRT (1949) stated that A. minor is entirely an Antarctic form. A. rostrata differs from $A$. trichechus in having long outer marginal spines on the 1st and 2 nd segments of the exopod of the lst leg.

Distribution and size variation:

\begin{tabular}{llccr} 
Author & Locality & Depth $(\mathrm{m})$ & \multicolumn{2}{c}{ Length $(\mathrm{mm})$} \\
& & & $q$ & \multirow{+}{*}{} \\
SARs, 1903 & Norwegian Sea & $500-1000$ & 4.40 & - \\
WITH, 1915 & North Altantic & $0-800$ & $3.4-3.9$ & - \\
BRODSKY, 1950 & Arctic Ocean & $400-2000$ & $4.0-4.4$ & - \\
TANAKA, 1957a & Izu region & $0-200,600-1000$ & 3.01 & 3.13 \\
Present record & Izu region & $0-620$ & $3.10-3.14$ & -
\end{tabular}

\section{CHIRIDIUS GIESBRECHT, 1892}

Chiridius armatus (BOECK, 1872)

(Fig. 2, a-k)

Euchaeta armata BoEcK, 1872, p. 39.

Chiridius armatus (BоEGK).-SARs, 1903, p. 27, pls. 15, 16; WITH, 1915, p. 77, text-fig. 17, pl. 2, fig. 3; Wilson, 1950, p. 189, pl. 22, fig. 310; MAtтhews, 1964, p. 6, figs. 2, 4-6.

Pseudaetideus armatus (Bozck).-Wolfenden, 1904, p. 115, pl. 9, figs. 29-31; Brodsky, 1950, p. 154, fig. 70 .

Occurrence: Sta. 93-1, 19; Sta. 108, 1 \%.

Descriptive notes: Female, $3.84 \mathrm{~mm}$. The cephalothorax and abdomen are in the proportional lengths $77: 23$. The integument is finely granulated. The head is fused with the 1st thoracic segment; the 4th and 5th segments are partially fused; the lateral expansions of the last thoracic segment extend nearly to the distal onethird of the genital segment. The frontal margin of the head is obtusely rounded. 
The rostrum is small, bifurcate; the rami are set close together; the basal part is not hollowed.

The abdominal segments and furca are in the following proportional lengths:

\begin{tabular}{lrrrrl} 
segment & $1-2$ & 3 & 4 & 5 & furca \\
\hline 46 & 15 & 15 & 9 & 15 & $=100$
\end{tabular}

The genital segment is 1.2 times as long as wide; all but the anal segment are striated on the distal margin; the furca is a little longer than wide.

The 1st antenna extends to the distal margin of the 2nd abdominal segment. The segments are in the following proportional lengths:

\begin{tabular}{lrrrrrrrrrrrrrr} 
segment & 1 & 2 & 3 & 4 & 5 & 6 & 7 & $8-9$ & 10 & 11 & 12 & 13 & 14 & 15 \\
\cline { 2 - 11 } & 72 & 69 & 29 & 26 & 29 & 29 & 29 & 61 & 26 & 29 & 29 & 32 & 35 & 37
\end{tabular}

\begin{tabular}{llllllllll}
16 & 17 & 18 & 19 & 20 & 21 & 22 & 23 & 24 & 25 \\
\hline 43 & 43 & 40 & 60 & 66 & 40 & 52 & 58 & 49 & $17=1000$
\end{tabular}

In the 2nd antenna the exopod is 1.3 times as long as the endopod; the endopod has 7 setae on the outer lobe, and 9 setae on the inner lobe. The mandibular palp has 2 marginal setae: there is a ridge with a row of spinules. The 1st maxilla has 7 long and 2 short setae on the outer lobe, 10 setae on the exopod, $6+3+4$ setae on the 3rd to 1 st segments of the endopod, 5 setae on the 2nd basal segment, 4 setae on each of the 3rd and 2nd inner lobes, and 14 setae on the 1st inner lobe. The 2nd maxilla has 6 long and 3 short setae on the apical portion; 3 setae on each of the 1 st to 5 th lobes. In the maxilliped the 2 nd basal segment is longer than the 1 st basal segment; the 1st lobe is represented by a very small seta.

The 1st leg has a 3-segmented exopod and 1-segmented endopod; the 1st segment of the exopod has an outer marginal spine reaching the distal margin of the 2nd segment. The 2nd leg has a 3-segmented exopod; the endopod is incompletely fused; the anterior surface of the exopod is provided with 3 cutaneous pores on the 3 rd segment, 3 pores on the 2 nd segment, and 1 pore on the 1 st segment; the endopod has 2 minute pores on the distal portion; the terminal spine of the exopod is furnished with 36 teeth. The 3rd leg has a 3-segmented exopod and 2-segmented endopod; the exopod has 3, 2 and 1 pores on the 3rd to 1 st segments respectively; there are no pores on the endopod; the terminal spine of the exopod has 33 teeth. The 4th leg has a 3-segmented exopod and endopod; the terminal spine of the exopod has 33 teeth.

Remarks: Although the present specimens have slightly shorter furcal rami, they agree fairly well with those described by SARs (1903) and W WTH (1915). Dr. J. BRADFORD (personal communication) of the New Zealand Oceanographic Institute has called attention to the number and position of the cutaneous pores on the 


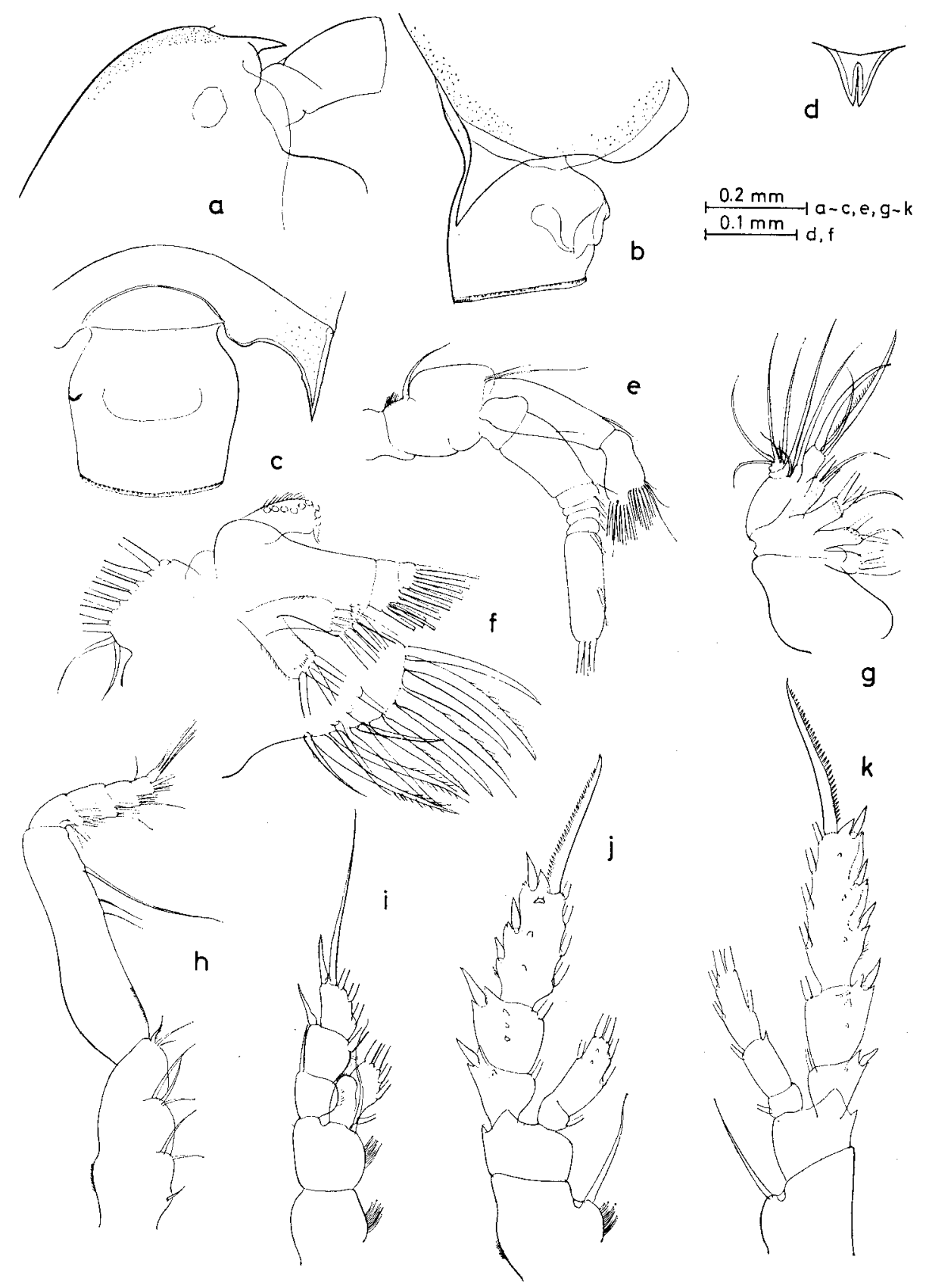

Fig. 2. Chiridius armatus (BoECK), female: a, head, lateral view; b, last thoracic segment and genital segment, lateral view; c, the same, dorsal view; d, rostrum; e, 2nd antenna; $f, 1$ st maxilla; g, 2nd maxilla; h, maxilliped; i, 1st leg; j, 2nd leg; k, 4th leg. 
swimming legs of copepods, and has stressed the importance of the pores for the identification of the species of Chiridius and Aetideopsis. Recently, MatThews (1964) showed several interesting biological features, i.e., annual cycle, development and seasonal size-fluctuations, of Chiridius armatus near the $240 \mathrm{~m}$ sea-floor off Bergen, Norway. He proposed that the name Pseudaetideus should be transferred to the genus Chiridius, because the characters given by WoLFEnden (1904) are insufficient for the establishment of the new genus.

Distribution and size variation:

\begin{tabular}{|c|c|c|c|c|}
\hline \multirow{2}{*}{ Author } & \multirow[t]{2}{*}{ Locality } & \multirow[t]{2}{*}{ Depth $(\mathrm{m})$} & \multicolumn{2}{|c|}{ Length (mm) } \\
\hline & & & 9 & $\hat{0}$ \\
\hline SARS, 1903 & Norwegian waters & $183-550$ & 4.0 & 4.0 \\
\hline FARRAN, 1903 & Off Ireland & 0 & 4.0 & - \\
\hline WOLFENDEN, 1904 & Faröe Channel & - & 3.68 & $<3.68$ \\
\hline WITH, 1915 & North Atlantic & $0-300$ & $3.60-4.43$ & 3.66 \\
\hline FARRAN, 1926 & Bay of Biscay & $366-730$ & $3.2-3.6$ & - \\
\hline WILSON, 1950 & Off Galapagos Is. & $0-550$ & - & - \\
\hline Brodsky, 1950 & Arctic Ocean & $<200$ & $3.3-4.2$ & $2.9-4.0$ \\
\hline VERVOORT, 1963 & Gulf of Guinea & $0-100$ & $3.20-3.60$ & - \\
\hline Matthews, 1964 & Off Bergen & near bottom $(240)$ & $2.8-3.6^{*}$ & $2.4-3.1^{*}$ \\
\hline Present record & Izu region & $0-620$ & $3.33-4.00$ & - \\
\hline
\end{tabular}

Chiridius gracilis FARRAN, 1908

Chiridius gracilis Farran, 1908, p. 30, pl. 2, figs. 1-3; TANAKA, 1937, p. 256, fig. 6; TANAKA, 1957a, p. 48, fig. 30; VЕRVOORT, 1957, p. 55.

Occurrence: Sta. 83, 8; Sta. 84-2, 9q; Sta. 93-1, 3q; Sta. 93-2, 1 9 ; Sta. 94, 5ㅇ; Sta. 95, 2q; Sta. 96, 1q; Sta. 97-2, 2q, 2ð; Sta. 98, 8q; Sta. 108, 9q, 2ð; Sta. 109, 3q; Sta. 110, 1우 10; Sta. 111-1, 4우 Sta. 111-2, 2q; Sta. 113, 3q; Sta. 115-1, 1 ; ; Sta. 120, 1q; Sta. 122, 1 \%

Remarks: Chiridius gracilis closely resembles C.poppei. The differences between these two species are discussed by Vervoort (1957).

Distribution and size variation:

\begin{tabular}{|c|c|c|c|}
\hline Author & Locality & Depth $(\mathrm{m})$ & $\begin{array}{l}\text { Length }(\mathrm{mm}) \\
\quad+\end{array}$ \\
\hline FARRAN, 1908 & Irish waters & $510-1830$ & $2.4-2.8$ \\
\hline A. Scott, 1909 & Malay Archipelago & $0-1000$ & 2.4 \\
\hline WITH, 1915 & North Atlantic & $0-1500$ & 2.69 \\
\hline SEWELL, 1929 & Arabian Sea & $0-1280$ & 2.2 \\
\hline
\end{tabular}




$\begin{array}{llccc}\text { FARRAN, 1936 } & \text { Great Barrier Reef } & 0-600 & 2.70 & - \\ \text { TANAKA, 1937 } & \text { Suruga Bay } & 250-500 & 2.57-2.64 & - \\ \text { WILson, 1950 } & \text { Philippine waters } & 0 & - & - \\ \text { TANAKA, 1957a } & \text { Izu region } & 0-1000 & 2.55 & 2.32 \\ \text { VERvoort, 1957 } & \text { Sub-antarctic } & 0-750 & 2.79 & - \\ \text { Present record } & \text { Izu region } & 0-360 & 2.40-2.87 & 2.03-2.25\end{array}$

Chiridius molestus TANAKA, 1957

Chiridius molestus TANAKa, 1957a, p. 53, fig. 33.

Occurrence: Sta. 93-1, 20.

Distribution and size variation:

\begin{tabular}{llccc} 
Author & Locality & Depth $(\mathrm{m})$ & Length $(\mathrm{mm})$ \\
& & & $\uparrow$ & \multirow{0}{*}{} \\
TANAKA, 1957a & Izu region & $0-1000$ & - & 2.36 \\
Present record & Izu region & $0-620$ & - & $2.02-2.13$
\end{tabular}

Chiridius poppei Giesbrecht, 1892

Chiridius poppei Giesbrecht, 1892, p. 224, pl. 14, figs. 14-18, pl. 36, figs. 10-12; TanakA, 1937, p. 254, fig. 5; 1957a, p. 50, fig. 31; Grice, 1962, p. 192, pl. 8, figs. 5-7.

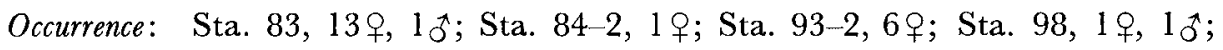

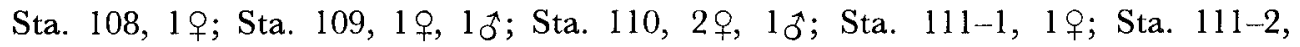
2q; Sta. 112, 1q; Sta. 113, 1q; Sta. 115-2, 1q; Sta. 116, 2 q

Distribution and size variation:

\begin{tabular}{|c|c|c|c|c|}
\hline \multirow[t]{2}{*}{ Author } & \multirow[t]{2}{*}{ Locality } & \multirow[t]{2}{*}{ Depth $(\mathrm{m})$} & \multicolumn{2}{|c|}{ Length (mm) } \\
\hline & & & 우 & $\widehat{\sigma}$ \\
\hline Giesbreaht, 1892 & Mediterranean Sea & - & 1.8 & - \\
\hline A. Scotr, 1909 & Tropical Atlantic & $0-1536$ & 1.8 & - \\
\hline WOLFENDEN, 1911 & North Atlantic & $0-3000$ & 1.9 & - \\
\hline SARs, 1925 & North Atlantic & $0-2025$ & 2.0 & - \\
\hline FARRAN, 1926 & Bay of Biscay & 183 & 1.92 & - \\
\hline FARRAN, 1929 & Off New Zealand & 0 & $1.92-2.00$ & - \\
\hline Rose, 1937 & Mediterranean Sea & - & - & 1.7 \\
\hline TANAKA, $1957 \mathrm{a}$ & Izu region & $200-400$ & $1.83-1.87$ & 1.52 \\
\hline Grice, 1962 & Tropical Pacific & $72-146$ & $1.59-1.83$ & - \\
\hline VERVOORT, 1963 & Gulf of Guinea & $0-\quad 10$ & 2.20 & - \\
\hline Present record & Izu region & $0-400$ & $1.76-2.26$ & $1.65-2.13$ \\
\hline
\end{tabular}




\section{GAIDIUS GIESBRECHT, 1895}

\section{Gaidius brevispinus (SARS, 1900)}

Chiridius brevispinus SARs, 1900, p. 68, pl. 19, figs. 1-11.

Gaidius brevispinus (SARs).-SARS, 1903, p. 162, suppl. pl. 6, fig. 2; WrTH, 1915, p. 94, text-fig. 24, pl. 2, fig. 7, pl. 3, fig. 1; TANAKA, 1957a, p. 62, fig. 38 a-c (क only).

Gaidius major Wolfenden, 1904, p. 114, pl. 9, figs. 7, 8.

Occurrence: Sta. 83, 1 ; Sta. 84-2, 1 + ; Sta. 108, 3q; Sta. 110, 1 9 ; Sta. 111-1, 1q; Sta. 111-2, 1q; Sta. 112, 1 ; Sta. 115-2, 1\%; Sta. 117-2, 1 ; Sta. 121-2, 2 q

Remarks: In the 2nd antenna of the female the exopod is about 1.5 times as long as the endopod; the endopod has 6 setae on the outer lobe and 7 setae on the inner lobe. The maxilliped has a lamella on the 1st basal segment. The 1st leg has 3-segmented exopod. The examination of the male specimen described by TANAKA (1957a) as G. brevispinus indicated that it was not G. brevispinus; it lacks the minute marginal spine on the 3rd segment of the exopod of the left 5 th leg. The TANAKA's male specimen may be $G$. brevicaudatus or $G$. intermedius.

Distribution and size variation:

Author

SARS, 1900

WOLFENDEN, 1904

WrTH, 1915

Brodsky, 1948

TANAKa, 1957 a

Present record
Locality

Arctic Ocean

Faröe Channel

Denmark Strait

Sea of Japan

Izu region

Izu region

\begin{tabular}{clc} 
Depth (m) & \multicolumn{2}{l}{ Length (mm) } \\
& \multicolumn{1}{c}{+} & o \\
- & 4.80 & - \\
- & 4.65 & 3.10 \\
$0-1800$ & 4.05 & 3.34 \\
$200-500$ & $3.9-4.8$ & $3.01-3.35$ \\
$0-1000$ & 4.4 & - \\
$0-740$ & $4.30-4.90$ & -
\end{tabular}

Gaidius pungens Giesbrecht, 1895

(Fig. 3, a-i)

Gaidius pungens GIESBRECht, 1895, p. 248, pl. 1, figs. 1-4; Vervoort, 1949, p. 10, fig. 4.

Gaidius tenuispinus (ô).-TANAKA, 1957a, p. 60, fig. $37 \mathrm{f}-\mathrm{k}$.

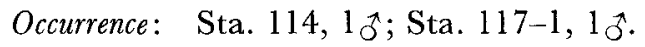

Descriptive notes: Male, $2.28 \mathrm{~mm}$. The cephalothorax and abdomen are in the proportional lengths 77:23. The cephalothorax is 2.3 times as long as wide. The last thoracic segment has lateral dorsal spines; the spines are slender, reaching the proximal one-third of the 1 st abdominal segment. The rostrum is uni-acuminate, though bifid at the apex; it is small and directed downward.

The abdominal segments and furca are in the following proportional lengths: 
segment

\begin{tabular}{rrrrrl}
1 & 2 & 3 & 4 & 5 & furca \\
\hline 20 & 28 & 20 & 15 & 4 & $13=100$
\end{tabular}

The 2nd to 4th segments are fringed with fine teeth on the distal margin; the furca is a little longer than wide.

The 1st antenna extends to the distal margin of the 4th abdominal segment; the segments are in the following proportional lengths:

$\begin{array}{lrrrrrrrrrrrrr}\text { segment } & 1 & 2 & 3 & 4 & 5 & 6 & 7 & 8-9-10 & 11 & 12-13 & 14 & 15 & 16 \\ \text { right } & 54 & 49 & 28 & 22 & 28 & 28 & 28 & 65 & 22 & 60 & 38 & 44 & 49 \\ \text { left } & 56 & 52 & 28 & 23 & 28 & 28 & 28 & 73 & 22 & 62 & 40 & 46 & 52\end{array}$

\begin{tabular}{lllllll}
17 & 18 & 19 & $20-21$ & 22 & 23 & $24-25$ \\
\hline 54 & 54 & 65 & 107 & 70 & 65 & $70=1000$ \\
46 & 52 & 69 & 108 & 64 & 58 & $64=1000$
\end{tabular}

In the 2nd antenna the exopod is slightly longer than the endopod; the 2nd segment of the exopod has 2 inner marginal setae; the endopod has 6 long setae on the outer lobe, and 5 long and 2 short setae on the inner lobe. The mandibular palp is small but robust, and has a marginal seta; the endopod has 9 setae. In the 1st maxilla the outer lobe has 7 setae; the exopod has 11 setae; the endopod including the 2nd basal segment has 10 setae; the 1 st to 3 rd inner lobes are reduced. The 2nd maxilla is considerably reduced. The maxilliped is slender; the 2nd basal segment is longer than the Ist basal segment; the endopod has $4,4,3,3+1$, and 4 setae on the 1 st to 5 th segments respectively.

In the 1st leg the 1st and 2nd segments of the exopod are fused; the 2nd segment of the exopod is furnished with a minute spine and a small process on the ourer distal margin; the 3rd segment of the exopod is furnished with a small process $c n$ the outer margin. The 2nd leg has a 3-segmented exopod and 1-segmented endopod; the terminal spine of the exopod has 27 teeth. The 3 rd and 4 th legs each have a $3-$ segmented exopod and endopod. The 5th pair of legs has a structure similar to that in G. tenuispinus; the endopod of the left leg is longer than half the length of the 1 st segment of the exopod of the same leg, and has a fine seta at the apex; the 2nd segment of the exopod of the left leg is swollen on the inner margin; the distal end of the same segment has a small brush of hairs.

Remarks: The male closely resembles G. tenuispinus or G. variabilis. However, it differs from them in its small size and in having a 1-segmented endopod in the 2nd leg. The endopod of the left 5 th leg is much shorter in proportion when compared with those of the latter 2 species. 


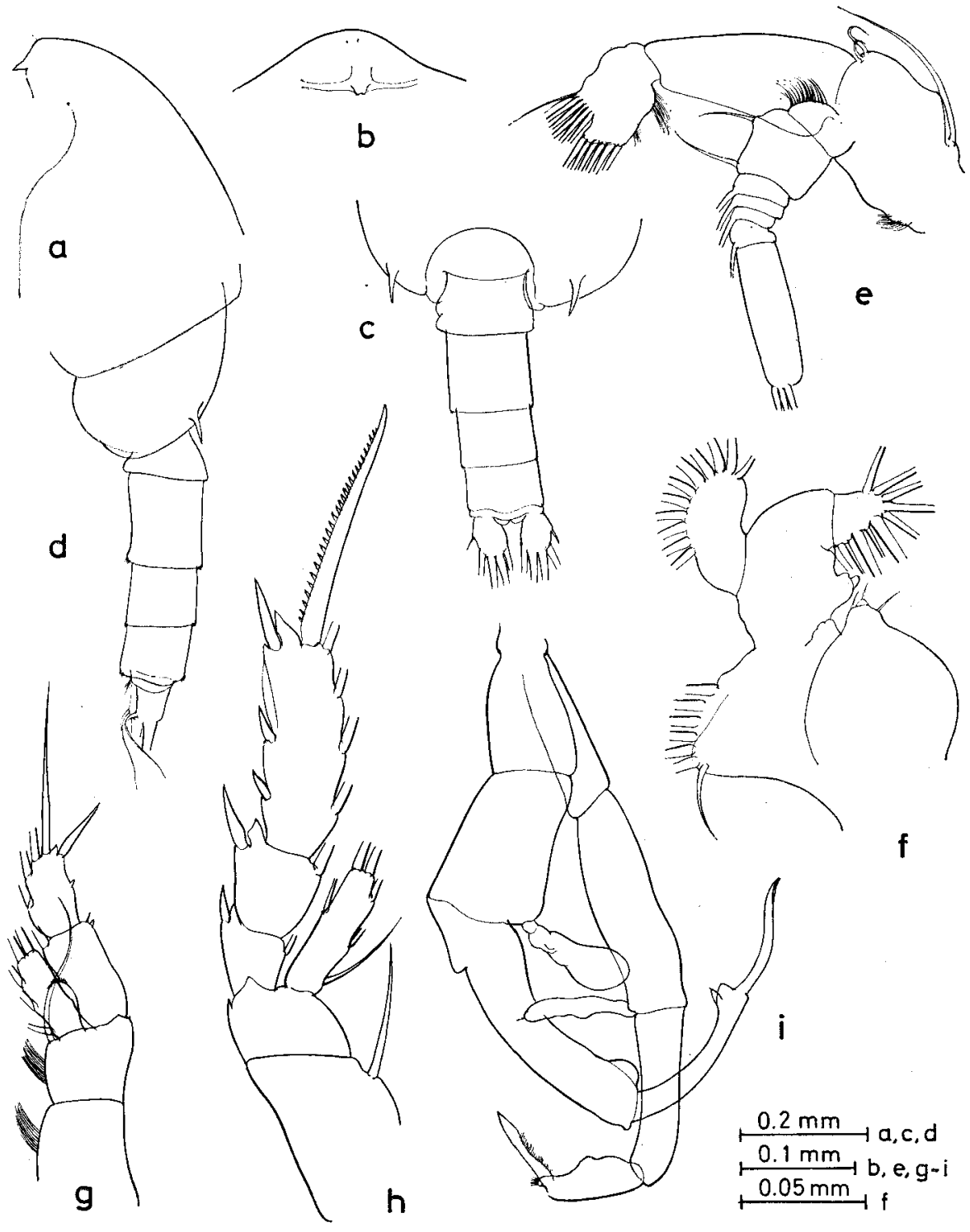

Fig. 3. Gaidius pungens Gresbrecht, male: $a$, head, lateral view; $b$, rostrum, ventral view; c, last thoracic segment and abdomen, dorsal view; d, the same, lateral view; e, 2nd antenna; f, 1st maxilla; g, 1st leg; h, 2nd leg; i, 5th pair of legs. 
Distribution and size variation:

\begin{tabular}{|c|c|c|c|c|}
\hline \multirow{2}{*}{ Author } & \multirow[t]{2}{*}{ Locality } & \multirow[t]{2}{*}{ Depth $(\mathrm{m})$} & \multicolumn{2}{|c|}{ Length (mm) } \\
\hline & & & ㅇ & o \\
\hline GIESBRECHT, 1895 & Off California & $0-550$ & 3.2 & - \\
\hline VERVOORT, 1949 & Flores Sea & $0-2000$ & 2.65 & - \\
\hline TANAKA, 1957a & Sagami Bay & $0-1000$ & - & 2.07 \\
\hline Present record & Izu region & $0-930$ & - & $2.08-2.28$ \\
\hline
\end{tabular}

Gaidius robustus (SARS, 1905)

(Fig. 4, a-h)

Gaetanus robustus SARs, 1905, p. 11; SARs, 1925, p. 63, pl. 19, figs. 1, 2.

Gaidius robustus (SARs).-Grice and Hulsemann, 1967, p. 24, figs. 60-64.

Mesogaidius maximus (Wolfenden).-Wolfenden, 1911, p. 224, text-fig. 13, pl. 26, figs. 3-6.

Pseudogaetanus robustus BRodsky, 1950, p. 168, fig. 86.

not Gaidius robustus VERvoort, 1949, p. 12, figs. 5, 6.

Occurrence: Sta. 117-1, 1q; Sta. 117-2,3․

Descriptive notes: Female, $8.95 \mathrm{~mm}$. The cephalothorax and abdomen are in the proportional lengths $82: 18$. The abdominal segments and furca are in the following proportional lengths:

\begin{tabular}{lrrrrr} 
segment & $\frac{1-2}{-2}$ & 3 & 4 & 5 & furca \\
\hline 43 & 14 & 10 & 10 & 23
\end{tabular}$=100$

The lst antenna extends to the end of the caudal furca; the segments are in the following proportional lengths:

\begin{tabular}{lrrrrrrrrrrrrrr} 
segment & 1 & 2 & 3 & 4 & 5 & 6 & 7 & $8-9$ & 10 & 11 & 12 & 13 & 14 & 15 \\
\cline { 2 - 10 } & 71 & 50 & 29 & 29 & 29 & 27 & 32 & 53 & 24 & 29 & 29 & 50 & 47 & 50
\end{tabular}

\begin{tabular}{ccccccccc}
16 & 17 & 18 & 19 & 20 & 21 & 22 & 23 & $24-25$ \\
\hline 47 & 53 & 50 & 63 & 58 & 45 & 58 & 50 & $27=1000$
\end{tabular}

In the 2nd antenna the exopod is 1.2 times as long as the endopod. The 1st maxilla has 9 setae on the outer lobe, 11 setae on the exopod, $7+4+4$ setae on the 3rd to lst segments of the endopod, 5 setae on the 2nd basal segment, 4 setae on the 3rd inner lobe, 5 setae on the 2 nd inner lobe, and 14 setae on the 1 st inner lobe. The maxilliped has a rounded lamella on the 1st basal segment.

In the Ist leg the lst and 2nd segments of the exopod are partially fused; the 2nd segment has an outer marginal spine. The 2nd leg has a 3-segmented exopod and 2 -segmented endopod. The 3rd and 4th legs each have a 3-segmented exopod and endopod; in the 4th leg the lst basal segment has 36 fine spinules on the inner margin. 


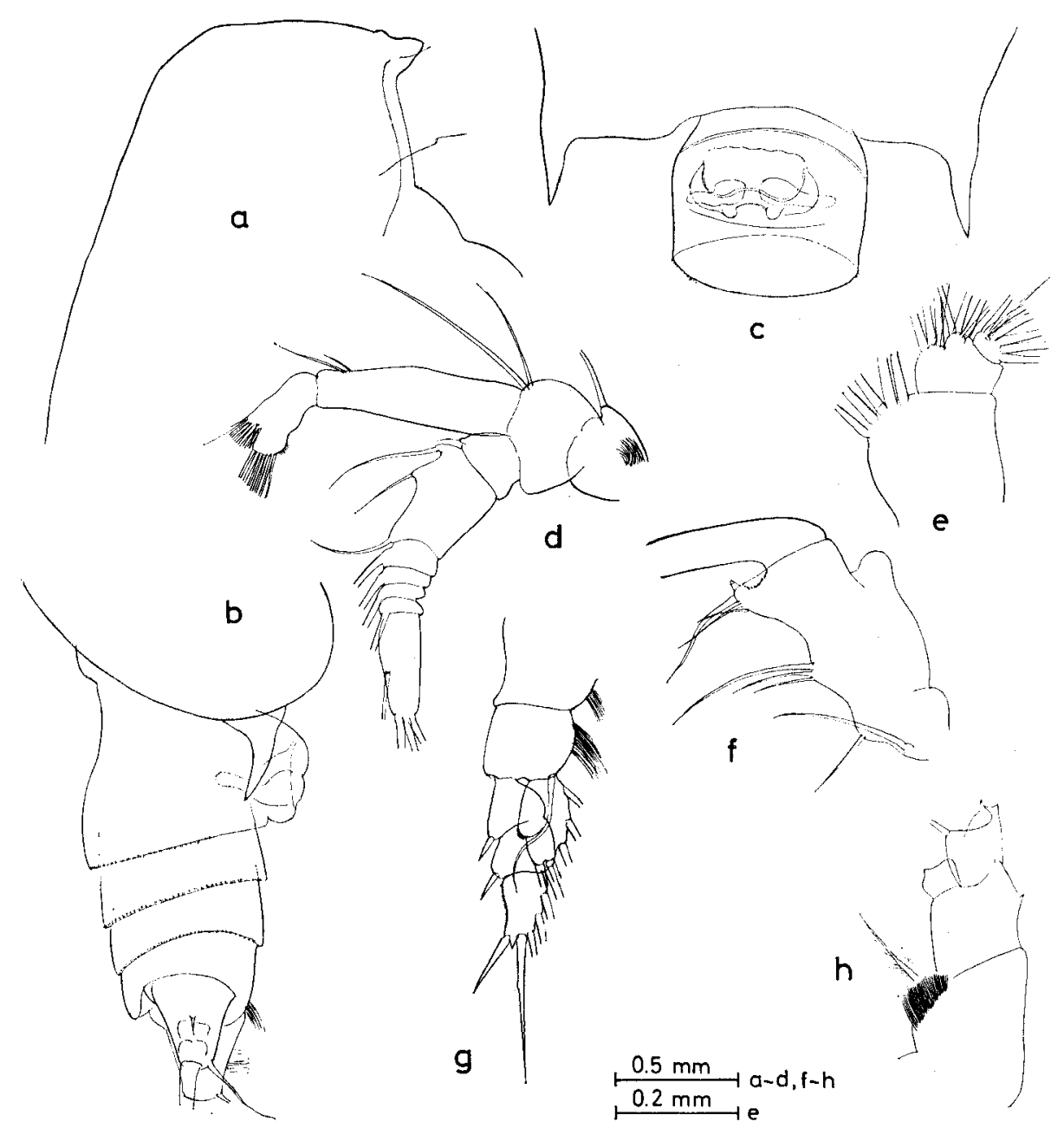

Fig. 4. Gaidius robusius (SARs), female: a, head, lateral view; b, last thoracic segment and abdomen, lateral view; c, genital segment, ventral view; d, 2nd antenna; e, endopod and 2nd basal segment of 1st maxilla; f, 1st basal segment of maxilliped; g, 1st leg; $\mathrm{h}$, proximal part of 4 th leg.

Remarks: Vervoort (1952a, b) redefined the genera Gaidius and Gaetanus. Accordingly some species, including Gaidius robustus, described as Gaetanus should be transferred to the genus Gaidius. The species has been reported from the northwestern Pacific as Pseudogaetanus robustus (Brodsky, 1950; TANAKa and Omori, 1967). Grice and Hulsemann (1967) stated that Gaidius robustus Vervoort is identical with G. intermedius WOLFENDEN. 
Distribution and size variation:

Author

WOLFENDEN, 1911

SARS, 1925

BRODSKY, 1950

Grice and

Hulsemann, 1967

Present record
Locality

South Atlantic

North Atlanctic

Northwestern Pacific

Arabian Sea

Izu region
Depth $(\mathrm{m}) \quad$ Length $(\mathrm{mm})$

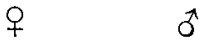

$\begin{array}{rlr}0-3000 & 7.5-8.0 & - \\ 0-1500 & 8.00 & - \\ 000-4000 & 7.5-9.0 & 7.0 \\ 350-1470 & - & -\end{array}$

$0-1100 \quad 8.95,9.65$

Gaidius tenuispinus (SARS, 1900)

(Fig. 5, a-n)

Chiridius tenuispinus SARs, 1900, p. 67, pl. 18, figs. 1-12.

Gaidius tenuispinus (SARs).-SARs, 1903, p. 162, suppl. pl. 6, fig. 1; WrTH, 1915, p. 89, text-fig. 23, pl. 2, fig. 8, pl. 3, fig. 2; Vervoort, 1949, p. 15, fig. 7; TANaka, 1957a, p. 60, fig. 37 a-e ( 9 only).

Occurrence: Sta. 83, 2q; Sta. 84-2, 1 \%; Sta. 94, 1q; Sta, 112, 1q; Sta. 122, 10 . Descriptive notes: Female, $3.65 \mathrm{~mm}$. The cephalothorax and abdomen are in the proportional lengths 79:21. The frontal margin of the head is rounded in dorsal view. The lateral spines of the last thoracic segment extend posteriorly to the distal margin of the genital segment. The rostrum is directed downward.

The abdominal segment and furca are in the following proportional lengths:

segment $\quad 1-2 \quad 3 \quad 4 \quad 5$ furca

$\begin{array}{lllll}40 & 16 & 13 & 11 & 20\end{array}=100$

The genital segment is as long as wide; the genital opening is well-developed.

The 1st antenna reaches the posterior margin of the 3rd abdominal segment. The segments are in the following proportional lengths:

\begin{tabular}{lrrrrrrrrrrrrrr} 
segment & 1 & 2 & 3 & 4 & 5 & 6 & 7 & $8-9$ & 10 & 11 & 12 & 13 & 14 & 15 \\
\cline { 2 - 10 } & 57 & 48 & 26 & 29 & 31 & 31 & 31 & 52 & 20 & 26 & 23 & 40 & 37 & 46
\end{tabular}

\begin{tabular}{llllllllll}
16 & 17 & 18 & 19 & 20 & 21 & 22 & 23 & 24 & 25 \\
\hline 49 & 49 & 50 & 63 & 57 & 46 & 63 & 57 & 49 & $20=1000$
\end{tabular}

The exopod of the 2nd antenna is about 1.3 times as long as the endopod; the endopod is furnished with 6 long setae and an appendicular seta on the outer lobe, and 8 long setae and an appendicular seta on the inner lobe. The exopod of the mandible palp is much longer than the endopod; the endopod is furnished with 8 long setae and a slender seta. The 1st maxilla has 9 setae on the outer lobe, 11 


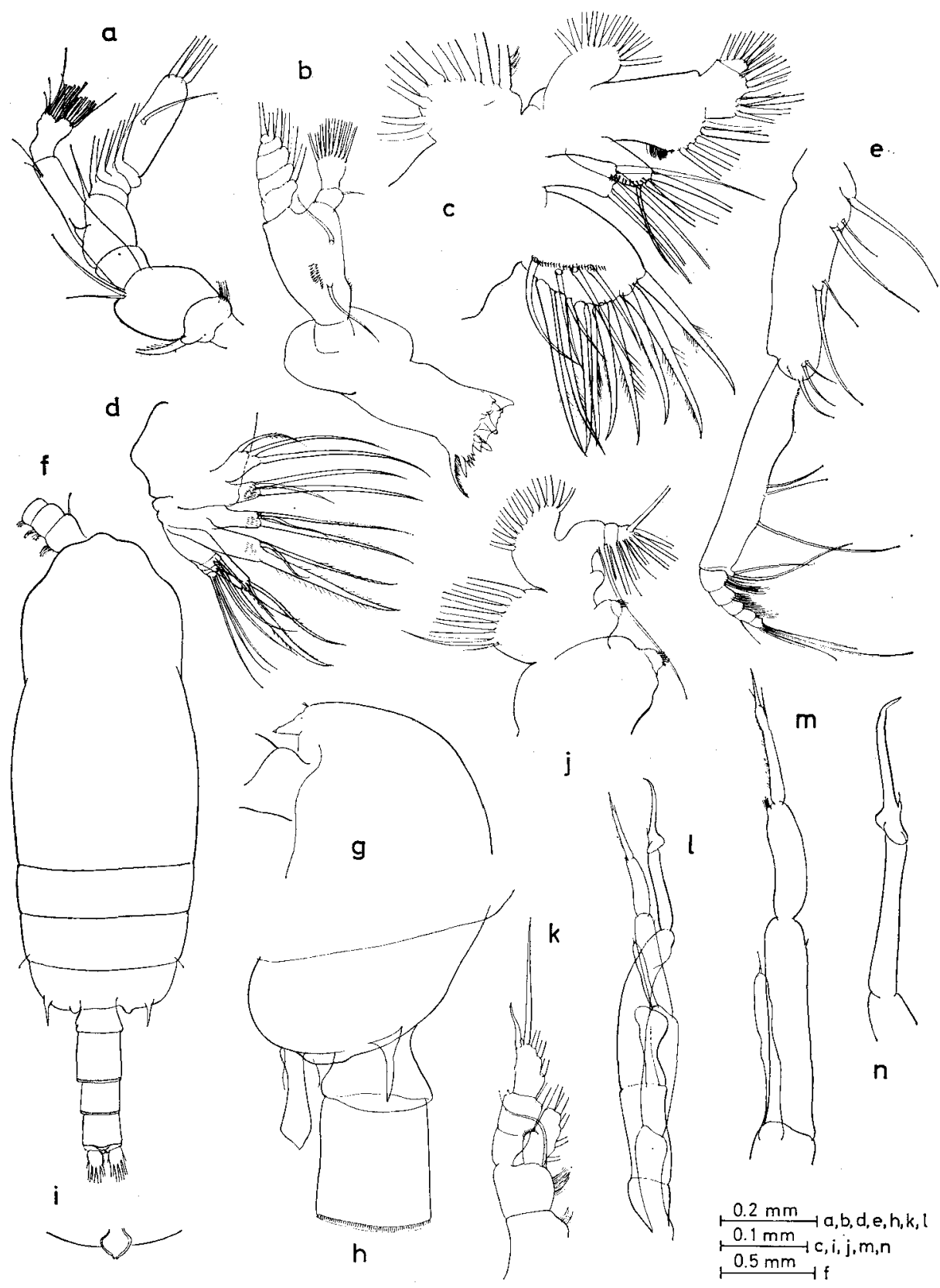

Fig. 5. Gaidius tenuispinus (SARs), female: a, 2nd antenna; b, mandible; c, 1st maxilla; d, 2nd maxilla; e, maxilliped. male: $f$, whole body, dorsal view; $g$, head, lateral view; $h$, last thoracic segment and abdominal segments, lateral view; $i$, rostrum; $j$, lst maxilla; $k$, lst leg; l, 5th pair of legs; $m$, distal part of left 5 th leg; $n$, distal part of right 5 th leg. 
setae on the exopod, $6+4+4$ setae on the 3rd to 1 st segments of the endopod, 5 setae on the 2 nd basal segment, 4 setae on the 3rd inner lobe, 4 setae on the 2nd inner lobe, and 14 setae on the 1st inner lobe. The 2nd maxilla has 6 long setae on the endopod; the 1st to 5 th lobes each have 3 setae. In the maxilliped there is no trace of a lamella on the anterior margin of the 1st basal segment.

In the 1st leg the 1 st and 2nd segments of the exopod are fused; there is a small marginal spine on the 2nd segment; the endopod is 1 -segmented. The 2nd leg has a 3-segmented exopod and 2-segmented endopod; the terminal spine of the exopod has 24 teeth. The 3rd and 4th legs each have a 3-segmented exopod and endopod; the terminal spine of the exopod of the 3rd leg has 21 teeth, and that of the 4th leg has 24 teeth; the 1 st basal segment of the 4 th leg has 12 tube-like spinules on the inner margin.

Male, $3.43 \mathrm{~mm}$. The cephalothorax and abdomen are in the proportional lengths $74: 26$. The cephalothorax is slender; it is 2.6 times as long as wide; the lateral spines of the last thoracic segment are long, reaching about the distal margin of the lst abdominal segment. The rostrum is directed downward, and is bifid at the apex.

The abdominal segments and furca are in the following proportional lengths:

segment

\begin{tabular}{rrrrrr}
1 & 2 & 3 & 4 & 5 & furca \\
\hline 20 & 29 & 21 & 15 & 3 & 12
\end{tabular}$=100$

The furca is slightly longer than wide.

The 1st antenna is short, reaching only the distal margin of the 3rd thoracic segment; the segments of the left antenna are in the following proportional lengths:

\begin{tabular}{lrrrrrrrrrrrrr} 
segment & 1 & 2 & 3 & 4 & 5 & 6 & 7 & $8-9-10$ & 11 & 12 & 13 & 14 & 15 \\
\cline { 2 - 11 } & 70 & 47 & 27 & 30 & 27 & 29 & 29 & 68 & 25 & 27 & 29 & 34 & 38
\end{tabular}

\begin{tabular}{cccccccc}
16 & 17 & 18 & 19 & $20-21$ & 22 & 23 & $24-25$ \\
\hline 45 & 47 & 55 & 68 & 111 & 68 & 62 & $64=1000$
\end{tabular}

The proximal 6 segments are fringed with scattered hairs on the posterior margin.

In the 2 nd antenna the endopod has 6 setae on the outer lobe, and 7 setae on the inner lobe. The 1st maxilla has 7 long setae and a small seta on the outer lobe, 11 setae on the exopod, 12 setae on the endopod including the 2nd basal segment; the 1 st to 3 rd inner lobes are reduced. The 2 nd maxilla is considerably reduced. The maxilliped is slender; the 1st and 2 nd basal segments are of equal lengths; there is no lamella on the 1st basal segment.

In the 1 st leg the 1st and 2nd segments of the exopod are partially fused; the 2nd segment of the exopod has a minute spine on the outer distal margin; the endopod is 1-segmented. The 2nd leg has a 3-segmented exopod and 2-segmented endopod; 
the terminal spine of the exopod has 28 teeth. The $3 \mathrm{rd}$ and 4 th legs each have a $3-$ segmented exopod and endopod; the terminal spine of the exopod of these legs each have 22 teeth. The 5th pair of legs agrees well with the description and figures of the same leg given by SARS (1903). In the left leg the endopod extends three-fourths the length of the 1st segment of the exopod; the 2nd segment of the exopod bears several minute setae on the distal margin; the 3rd segment is slender, and about as long as the 2nd segment; it bears minute setae along the inner margin, and is terminated with a fairly long spine; the 3 rd segment also has an outer marginal spine on the distal portion.

Remarks: The female is characterized in having long lateral spines on the last thoracic segment, reaching the distal margin of the genital segment. The male described by Tanaka (1957a) as G. tenuispinus is G. pungens.

Distribution and size variation:

\begin{tabular}{|c|c|c|c|c|}
\hline \multirow[t]{2}{*}{ Author } & \multirow[t]{2}{*}{ Locality } & \multirow[t]{2}{*}{ Depth (m) } & \multicolumn{2}{|c|}{ Length (mm) } \\
\hline & & & q & o \\
\hline SARs, 1900,1903 & Arctic Ocean & - & 3.80 & 2.0 \\
\hline WOLFENDEN, 1911 & Atlantic & 400 & 3.25 & - \\
\hline ESTERLy, 1911 & Off San Diego & $0-600$ & - & 3.10 \\
\hline WIтн, 1915 & Denmark Strait & $0-100$ & $3.22-2.84$ & 3.01 \\
\hline FARRAN, 1929 & Antarctic waters & $500-1750$ & $3.35-3.60$ & 3.25 \\
\hline VERVOORT, 1949 & Celebes Sea & $0-2500$ & $3.60-3.75$ & - \\
\hline VERVOORT, 1957 & Antarctic waters & $250-1000$ & $3.00-3.75$ & $2.97-3.20$ \\
\hline TANAKA, $1957 \mathrm{a}$ & Izu region & $0-1000$ & 3.44 & - \\
\hline $\begin{array}{l}\text { GriGe and } \\
\text { HulsEMANN, } 1967\end{array}$ & Tropical Indian Ocean & $1000-2000$ & - & - \\
\hline Present record & Izu region & $0-740$ & $3.30-3.65$ & 3.43 \\
\hline
\end{tabular}

Gaidius variabilis BRODSKY, 1950

(Fig. 6, a-k)

Gaidius variabilis Bronsky, 1950, p. 160, fig. 74 .

Gaidius moderatus TANAKA, 1957a, p. 66, fig. 40.

Occurrence: Sta. 83, 1\%; Sta. 84-2, 2\%; Sta. 108, 4q; Sta. 109, 2q; Sta. 121-2, 1 우; Sta. 122, 3 우.

Descriptive notes: Female, $3.55 \mathrm{~mm}$. The cephalothorax and abdomen are in the proportional lengths 79:21. The head is fused with the lst thoracic segment, as are the 4th and 5th thoracic segments. The cephalothorax is 1.6 times as long as wide. The frontal margin of the head is rounded. The lateral spines of the last thoracic segment extend to about one-third the length of the genital segment, though 


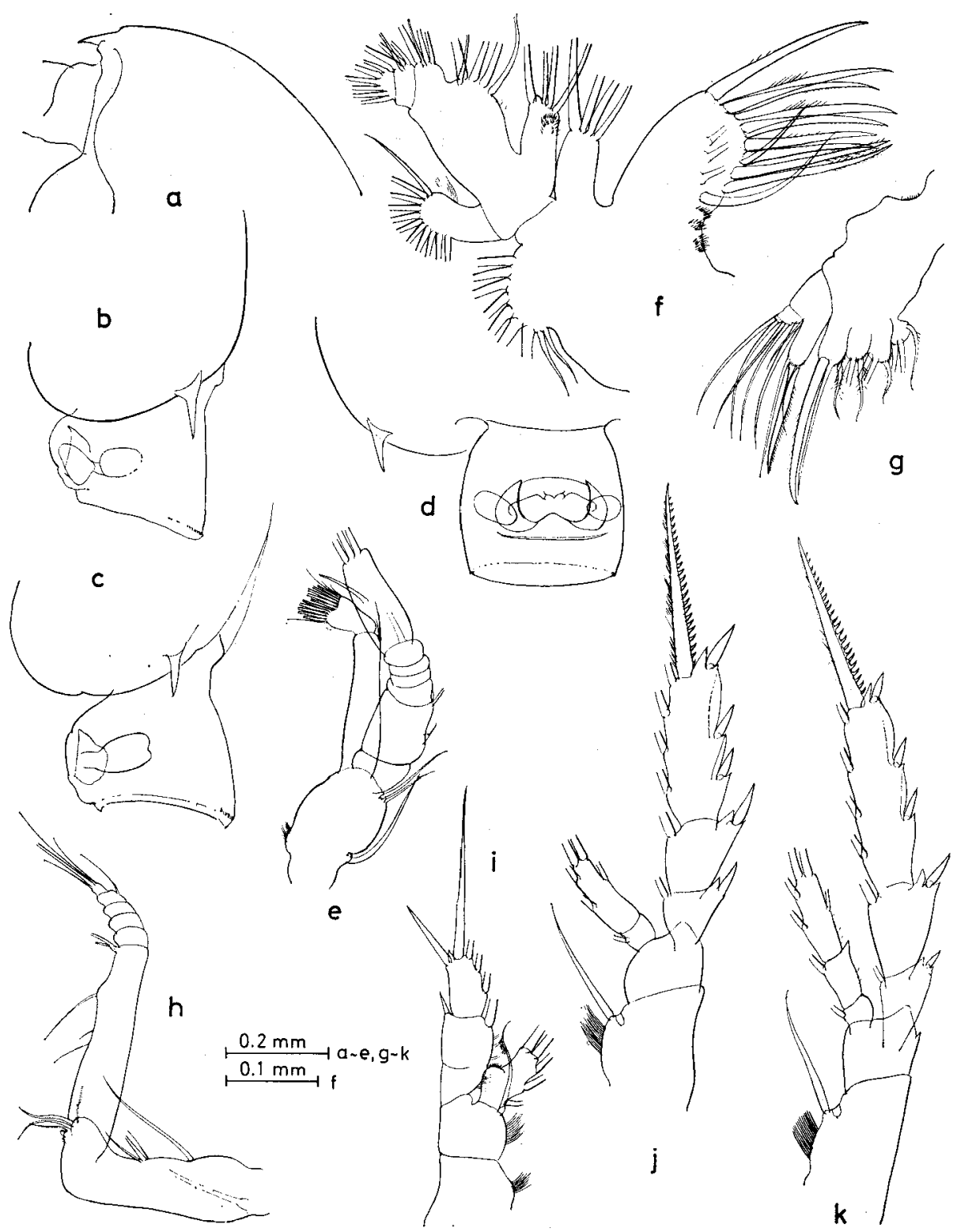

Fig. 6. Gaidius variabilis Brodsky, female: a, head, lateral view; b, last thoracic segment and genital segment, lateral view; $c$, the same, another specimen; d, genital segment, ventral view; e, 2nd antenna; f, 1st maxilla; $g$, 2nd maxilla; $h$, maxilliped; i, lst leg; j, 2nd leg; $k$, 4th leg.

they vary somewhat in size as shown in the figures; the spines are wide at the base. The rostrum is rather robust and directed downward.

The abdominal segments and furca are in the following proportional lengths: 


\begin{tabular}{lrrrrr} 
segment & $1-2$ & 3 & 4 & 5 & furca \\
\cline { 2 - 5 } & 40 & 17 & 14 & 11 & 18
\end{tabular}$=100$.

The genital segment is as long as wide; it and the following 2 segments are fringed with teeth on the distal margin; the furca is 1.3 times as long as wide.

The lst antenna extends to the distal margin of the 3rd abdominal segment; the segments are in the following proportional lengths:

\begin{tabular}{lrrrrrrrrrrrrrr} 
segment & 1 & 2 & 3 & 4 & 5 & 6 & 7 & $8-9$ & 10 & 11 & 12 & 13 & 14 & 15 \\
\cline { 2 - 11 } & 75 & 56 & 25 & 28 & 25 & 25 & 25 & 48 & 22 & 25 & 25 & 40 & 40 & 45
\end{tabular}

\begin{tabular}{ccccccccc}
16 & 17 & 18 & 19 & 20 & 21 & 22 & 23 & $24-25$ \\
\hline 45 & 48 & 51 & 62 & 57 & 45 & 63 & 57 & $68=1000$
\end{tabular}

In the 2nd antenna the exopod is a little longer than the endopod; the endopod is furnished with $6+1$ setae on the outer lobe, and 8 setae on the inner lobe, of which the innermost is very small. The mandibular palp bears 3 marginal setae; the endopod has 9 setae on the distal margin. The 1st maxilla has 9 setae on the outer lobe, 11 setae on the exopod, $6+4+4$ on the 3 rd to 1 st segments of the endopod, 5 setae on the 2nd basal segment, 4 setae and a small process on the 3rd inner lobe, 4 setae on the 2 nd inner lobe, and 14 setae on the 1 st inner lobe. The 2nd maxilla is of the usual structure; the endopod has 2 setae on each of the 1st to 3rd segments. In the maxilliped there is no lamella on the outer margin of the 1st basal segment; the proximal seta of the 1st basal segment is long.

In the 1st leg the 1st and 2nd segments of the exopod are fused; there is no trace of the outer marginal spine on the 1st segment; the spine of the 2nd segment extends to the proximal one-third of the next segment. The 2nd leg has a 3-segmented exopod and 2-segmented endopod; the terminal spine of the exopod has 24 teeth. The 3rd and 4th legs each have a 3-segmented exopod and endopod; the terminal spine of the exopod of the 3rd leg has 20 teeth; the 1st basal segment of the 4th leg has 16 tube-like spinules.

Remarks: Gaidius variabilis allied to $G$. tenuispinus, but is distinguished from the latter in having short lateral spines on the last thoracic segment which scarcely extend one-third the length of the genital segment.

\section{Distribution and size variation:}

\begin{tabular}{|c|c|c|c|c|}
\hline \multirow[t]{2}{*}{ Author } & \multirow[t]{2}{*}{ Locality } & \multirow[t]{2}{*}{ Depth $(\mathrm{m})$} & \multicolumn{2}{|c|}{ Length (mm) } \\
\hline & & & 우 & $\hat{o}$ \\
\hline BRODSKY, 1950 & Bering Sea & $<200$ & $3.2-3.6$ & $3.0-3.2$ \\
\hline TANAKA, $1957 \mathrm{a}$ & Izu region & $0-1000$ & 3.53 & 3.19 \\
\hline Present record & Izu region & $0-740$ & $3.20-3.82$ & 3.65 \\
\hline
\end{tabular}




\section{Gaidius species}

(Fig. 7, a-f)

Occurrence: Sta. 121-2, 13.

Descriptive notes: Male, $3.65 \mathrm{~mm}$. The cephalothorax and abdomen are in the proportional lengths $73: 27$. The cephalothorax is robust and 2.3 times as long as wide. The frontal margin of the head is more obtusely rounded than that of G. tenuispinus. The lateral spines of the last thoracic segment extend a little beyond the middle of the 1st abdominal segment. The rostrum is one-pointed, and bifid at the apex; it is directed downward.

The abdominal segments and furca are in the following proportional lengths:

\begin{tabular}{lrrrrrr} 
segment & 1 & 2 & 3 & 4 & 5 & furca \\
\cline { 2 - 6 } & 16 & 29 & 24 & 15 & 3 & 13
\end{tabular}$=100$

The 2nd and 3rd segments are striated with fine spinules on the distal margin; the furca is about 1.4 times as long as wide.

The 1st antenna extends about to the distal margin of the thorax; the segments of the left antenna are in the following proportional lengths:

\begin{tabular}{lrrrrrrrrrrrrrr} 
segment & 1 & 2 & 3 & 4 & 5 & 6 & 7 & 8 & $-9-10$ & 11 & $12-13$ & 14 & 15 & 16 \\
\cline { 2 - 10 } & 90 & 46 & 23 & 23 & 29 & 26 & 29 & 65 & 23 & 54 & 29 & 40 & 46
\end{tabular}

\begin{tabular}{ccccccc}
17 & 18 & 19 & $20-21$ & 22 & 23 & $24-25$ \\
\hline 50 & 54 & 64 & 105 & 68 & 68 & $68=1000$
\end{tabular}

The proximal 6 segments are each fringed with scattered spinules on the posterior margin.

The 2nd antenna has the exopod nearly as long as the endopod; the 1st segment of the exopod has hairs on the inner margin; the endopod has 6 setae on the outer lobe and 7 setae on the inner lobe. The mandible is robust; the 2 nd basal segment has a small marginal seta; the endopod has 9 setae on the distal margin. The 1st maxilla is similar to that of $G$. tenuispinus. The 2 nd maxilla is considerably reduced. The maxilliped has a similar structure to that of $G$. tenuispinus; the endopod has 4 , $4,3,3+1$, and 4 setae on the 1 st to 5 th segments.

In the 1st leg the 1st and 2nd segments of the exopod are fused; there is a minute distal spine on the outer margin of the 2nd segment of the exopod. In the 2nd leg the endopod is 2-segmented; the terminal spine of the exopod has 25 teeth. The 3rd and 4th legs each have 20 teeth on the terminal spine of the exopod. The 5th pair of legs resembles closely that of $G$. tenuispinus, but differs from that of the latter in the structure of the endopod of the left leg; the 3rd segment of the exopod has no outer marginal spine. 


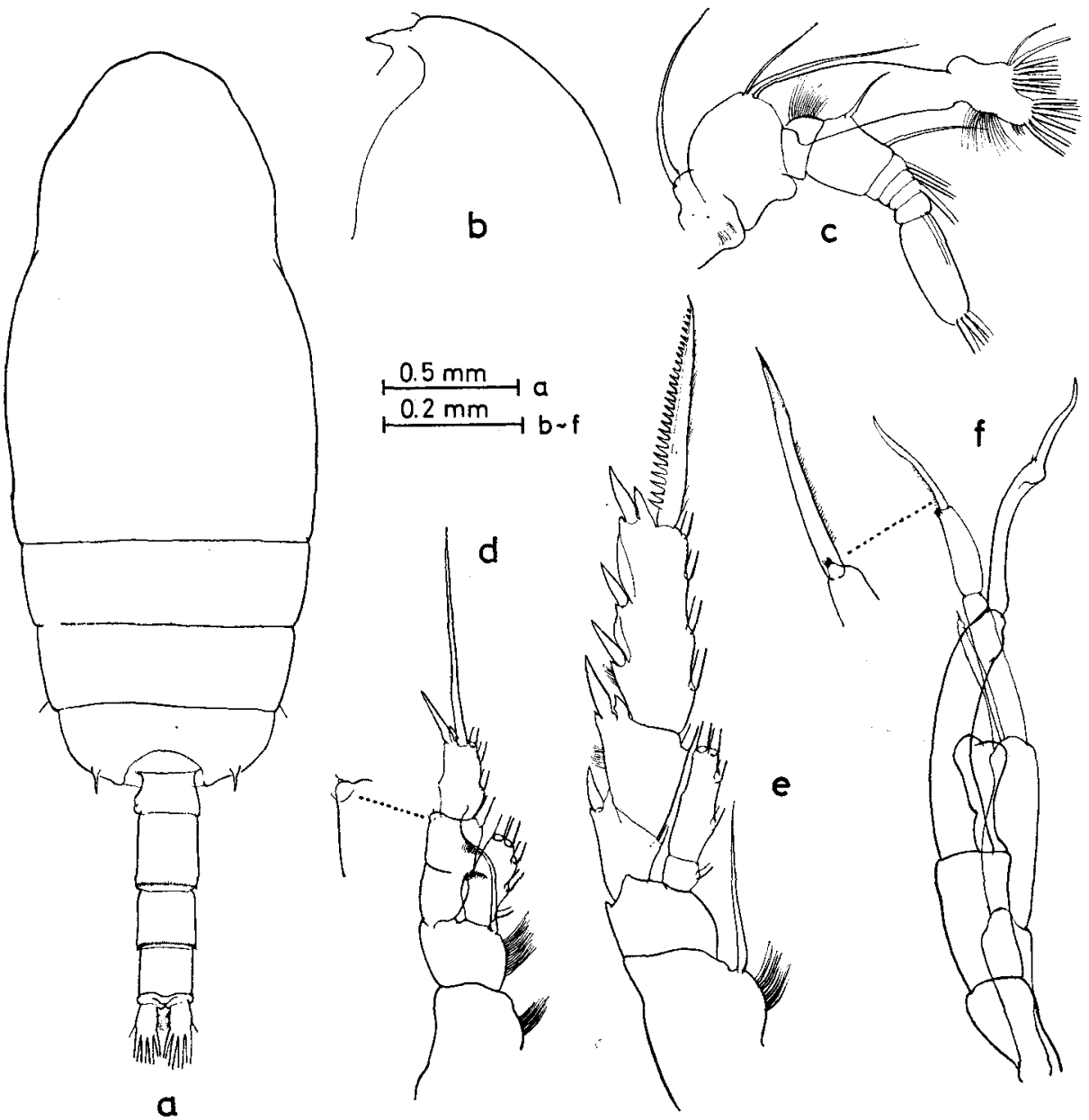

Fig. 7. Gaidius species, male: a, whole body, dorsal view; b, head, lateral view; c, 2nd antenna; d, 1st leg; e, 2nd leg; f, 5th pair of legs.

\section{GAETANUS GIESBRECht, 1888}

\section{Gaetanus ?antarcticus Wolfenden, 1905}

(Fig. 8, a-e)

Gaetanus antarcticus Wolfenden, 1905, p. 7, pl. 3, fig. 1; Wolfenden, 1908, p. 30, pl. 3, fig. 6; Sewell, 1947, p. 65, text-fig. 11; Vervoort, 1957, p. 62, figs. 41-43.

Occurrence: Sta. 115-2, 1ð(juv.).

Remarks: Copepodite V stage male, $6.60 \mathrm{~mm}$. The specimen has a damaged cephalic spine. The abdomen is 4-segmented. The 5th pair of legs is asymmetrical, and the left leg is robust. The large size and the shape of the cephalic spine and 

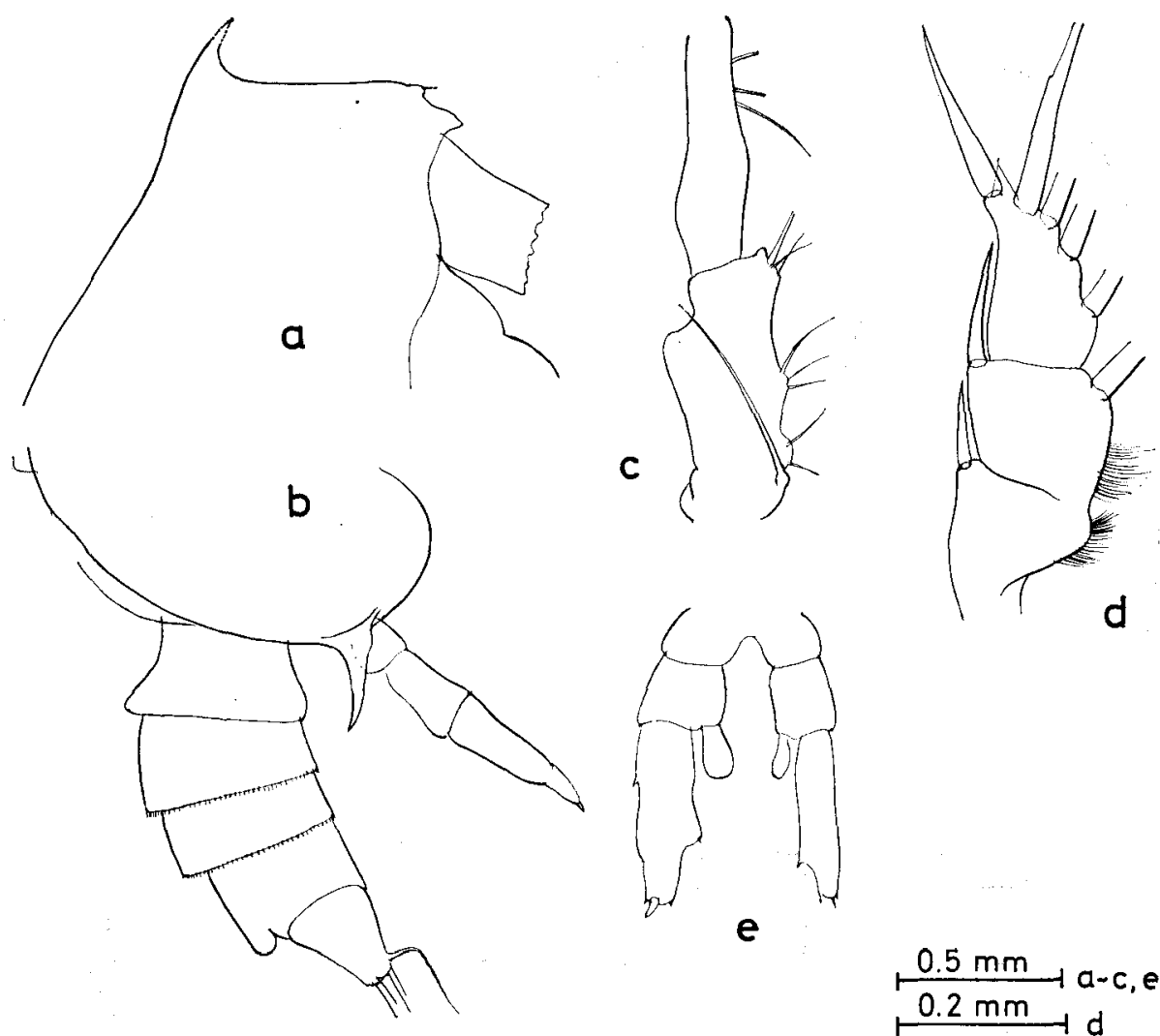

Fig. 8. Gaetanus ?antarcticus Wolfenden, immature male: a, head, lateral view; b, last thoracic segment and abdomen, lateral view; c, maxilliped; d, exopod of Ist Ieg; e, 5th pair of legs.

the lateral spines of the last thoracic segment appear to be good characters of the immature male of $G$. antarcticus. The occurrence of the present species is the first record in Japanese waters.

Distribution and size variation:

Author

Locality

WOLFENDEN, 1911

FARRAN, 1929

SEWEll, 1947

VERVOORT, 1957

GRICE and

Hulsemann, 1968

Present record
Antarctic waters

Antarctic waters

Arabian Sea

Antarctic waters

Southeastern Pacific

Izu region
Depth (m) Length (mm)

\begin{tabular}{rcc} 
& \multirow{2}{\text{P}}{} & $\hat{0}$ \\
$0-2000$ & 8.0 & - \\
$0-1000$ & - & 6.1 (juv.) \\
$0-1500$ & $7.60-8.25$ & - \\
$800-1000$ & $8.40-8.78$ & - \\
$0-600$ & - & -
\end{tabular}

$0-1100$

6.60 (juv.) 


\section{Gaetanus armiger GIESBREChT, 1888}

Gaetanus armiger Giesbrecht, 1888, p. 335; Giesbrecht, 1892, p. 219, pl. 14, figs. 19, 20, 22, 23, 26, 28, 29, pl. 36, figs. 2, 4, 5; A. Scotr, 1909, p. 45, pl. 8, figs. 16-22; MoRI, 1937, p. 40, pl. 17, figs. 8-13; Tanaka, 1957 b, p. 172, fig. 42 a-d.

Gaetamus simplex BRodsky, 1950, p. 163, fig. 77.

Occurrence: Sta. 97-2, 1 ㅇ․

Distribution and size variation:

Author

Giesbrecht, 1892

A. SсотT, 1909

SARs, 1925

Sewell, 1929

JeSpersen, 1934

MORI, 1937

Davis, 1949

Brodsky, 1950

TANAKA, $1957 \mathrm{~b}$

VERVOORT, 1963

Present record
Locality

Central Pacific

Malay Archipelago

North Atlantic

Bay of Bengal

Davis Strait

Off Cape Kinkazan

Northeastern Pacific

Northwestern Pacific

Sagami Bay

Gulf of Guinea

Izu region
Depth $(\mathrm{m})$ Length (mm)

$0-1800 \quad 3.2$

$0-900$

$0-5000$

0- 730

$0-800$

$0-100$

$0-1100$

$3.0-4.7$

3.2

$0-1000$

3.37

$0-600$

$2.95-3.05$

$0-800$

Gaetanus brevicornis ESTERLY, 1906

(Fig. 9, a-g)

Gaetanus brevicornis Esterly, 1906, p. 56, pl. 9, fig. 4, pl. 12, fig. 55; Sewell, 1947, p. 60, fig. 9. Gaetanus rectus Wolpenden, 1911, p. 232, fig. 18, pl. 26, figs. 14-16.

Gaetanus ascendens EsterLy, 1913, p. 182, pl. 10, figs. 1, 3, 6, pl. 11, fig. 39, pl. 12, fig. 56.

Occurrenct: Sta. 94-1, 1q; Sta. 114, 1 9 ; Sta. 121-2, 1 ㅇ․

Descriptive notes: Female, $4.84 \mathrm{~mm}$. The cephalothorax and abdomen are in the proportional lengths 79:21. The cephalothorax is 2.6 times as long as wide. The cephalic spine is small, directed downward. The last thoracic segment is provided with short but strong spines which are directed outward in dorsal view, and backward in lateral view.

The abdominal segments and furca are in the following proportional lengths:

\begin{tabular}{lrrrrl} 
segment & $1-2$ & 3 & 4 & 5 & furca \\
\cline { 2 - 6 } & 47 & 13 & 10 & 10 & 20
\end{tabular}$=100$

The genital segment is a little longer than wide. The genital to 4 th segments are 


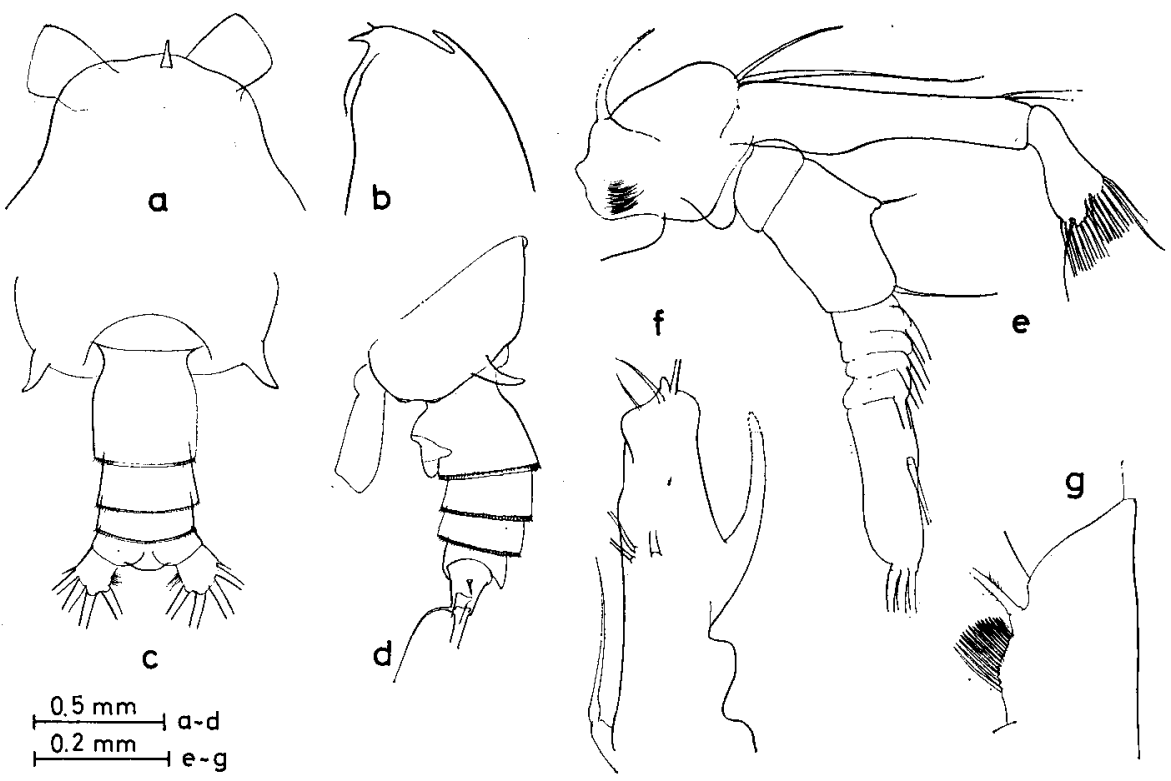

Fig. 9. Gaetanus brevicornis Esterly, female: a, head, dorsal view; b, the same, lateral view; c, last thoracic segment and abdomen, dorsal view; $d$, the same, lateral view; e, 2nd antenna; f, 1st basal segment of maxilliped; $g$, 1st basal segment of 4th leg.

fringed with fine teeth on the distal margin. The furca is slightly longer than wide.

The 1st antenna reaches the end of the furca; the segments are in the following proportional lengths:

\begin{tabular}{lrrrrrrrrrrrrrr} 
segment & 1 & 2 & 3 & 4 & 5 & 6 & 7 & $8-9$ & 10 & 11 & 12 & 13 & 14 & 15 \\
\cline { 2 - 12 } & 53 & 49 & 26 & 24 & 28 & 28 & 30 & 45 & 20 & 26 & 30 & 45 & 47 & 49
\end{tabular}

\begin{tabular}{llllllllll}
16 & 17 & 18 & 19 & 20 & 21 & 22 & 23 & 24 & 25 \\
\hline 49 & 51 & 51 & 63 & 55 & 49 & 60 & 55 & 47 & 20
\end{tabular}$=1000$

In the 2nd antenna the exopod is a little longer than the endopod; the endopod has 7 setae on the outer lobe and $7+1$ setae on the inner lobes. The 1st maxilla is furnished with the following number of setae on the various lobes; 9 on the outer lobe, 11 on the exopod, $6+4+4$ on the 3 rd to 1 st segments of the endopod, 5 on the 2nd basal segment, 4 on the 3rd inner lobe, 4 on the 2 nd inner lobe, and 13 on the 1st inner lobe. The 2nd maxilla has no characteristic features. The maxilliped is furnished with a long lamella on the anterior margin of the 1st basal segment; according to Sewell (1947) this process reaches well beyond the distal margin of the segment.

In the lst leg the 1st and 2nd segments of the exopod are partially fused; there is no marginal spine on the 2nd segment of the exopod. The 2nd leg has a 3 -seg- 
mented exopod and 2-segmented endopod. The 3rd and 4th legs each have a 3 -segmented exopod and endopod. In the 4th leg the 1st basal segment has about 16 tube-like spinules on the inner margin of the lst basal segment.

Remarks: There is no difference between Gaetanus brevicornis and G. ascendens ESTERLY in the shape of the head and the lateral spines of the last thoracic segment. Although VERVOoRT (1963) pointed out a fairly large discrepancy in size between the two species, $G$. ascendens is apparently a synonym of $G$. brevicornis. This is the first record of occurrence of the species from Japanese waters.

\section{Distribution and size variation:}

Author
EsterLy, 1906
SEWELL, 1929
SEWELL, 1947
VERVOORT, 1963
Present record

Present record
Locality

Off San Diego
Bay of Bengal
Arabian Sea
Gulf of Guinea
Izu region

Off San Diego$$
\text { Arabian Sea }
$$$$
\text { Izu region }
$$

\begin{tabular}{|c|c|}
\hline Depth (m) & $\begin{array}{l}\text { Length }(\mathrm{mm}) \\
\text { o }\end{array}$ \\
\hline $0-730$ & 4.3 \\
\hline $0-366$ & 3.7 \\
\hline $0-1500$ & $4.27,4.98$ \\
\hline $0-600$ & $4.60,4.65$ \\
\hline $0-930$ & $4.50-4.80$ \\
\hline
\end{tabular}

\section{Gaetanus kruppii GIESBRECHT, 1903}

(Fig. 10, a-g)

Gaetanus kruppii Gresbreght, 1903, p. 202, pl. 7, fig. 8, pl. 8, fig. 29; A. Scotт, 1909, p. 48, pl. 9, figs. 9-15, pl. 10, figs. 1-9; SARs, 1925, p. 61, pl. 18, figs. 5-8; SEWELl, 1947, p. 62, fig. 10; TANAKA, 1957b, p. 169, fig. 41; Vervoort, 1963, p. 126.

Gaetanus major (Wolfenden).-Wolfenden, 1904, p. 114, pl. 9, figs. 7, 8.

Occurrence: Sta. 83. 3q; Sta. 93-2, 3q; Sta. 94, 1q; Sta. 95, 1q; Sta. 97-2,

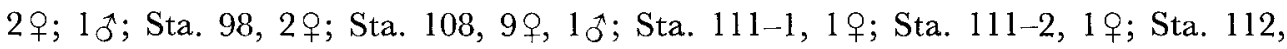
1 ㅇ, 1§; Sta. 113, 2q; Sta. 114, 1, 1ठ; Sta. 115-1, 4q; Sta. 115-2, 4q; Sta. 117-1, $2 q$; Sta. 117-2, 1; Sta. 119, 1 $q$; Sta. 120, 1q; Sta. 121-1, 2q; Sta. 121-2, 5q, 1 ; Sta. 122, 1우 1 \%

Discriptive notes: Male, $4.70 \mathrm{~mm}$. The cephalothorax and abdomen are in the proportional lengths $77: 23$. The cephalothorax is 2.7 times as long as wide. The lateral spines of the last thoracic segment extend about half of the length of the 1 st abdominal segment. The rostrum is notched slightly at the apex.

The abdominal segments and furca are in the following proportional lengths:

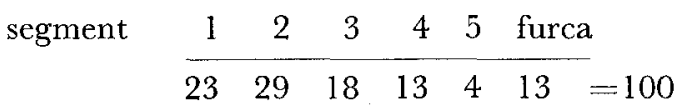

The 2 nd to 4 th segments are fringed with fine teeth on the distal margin. The furca is as long as wide. 


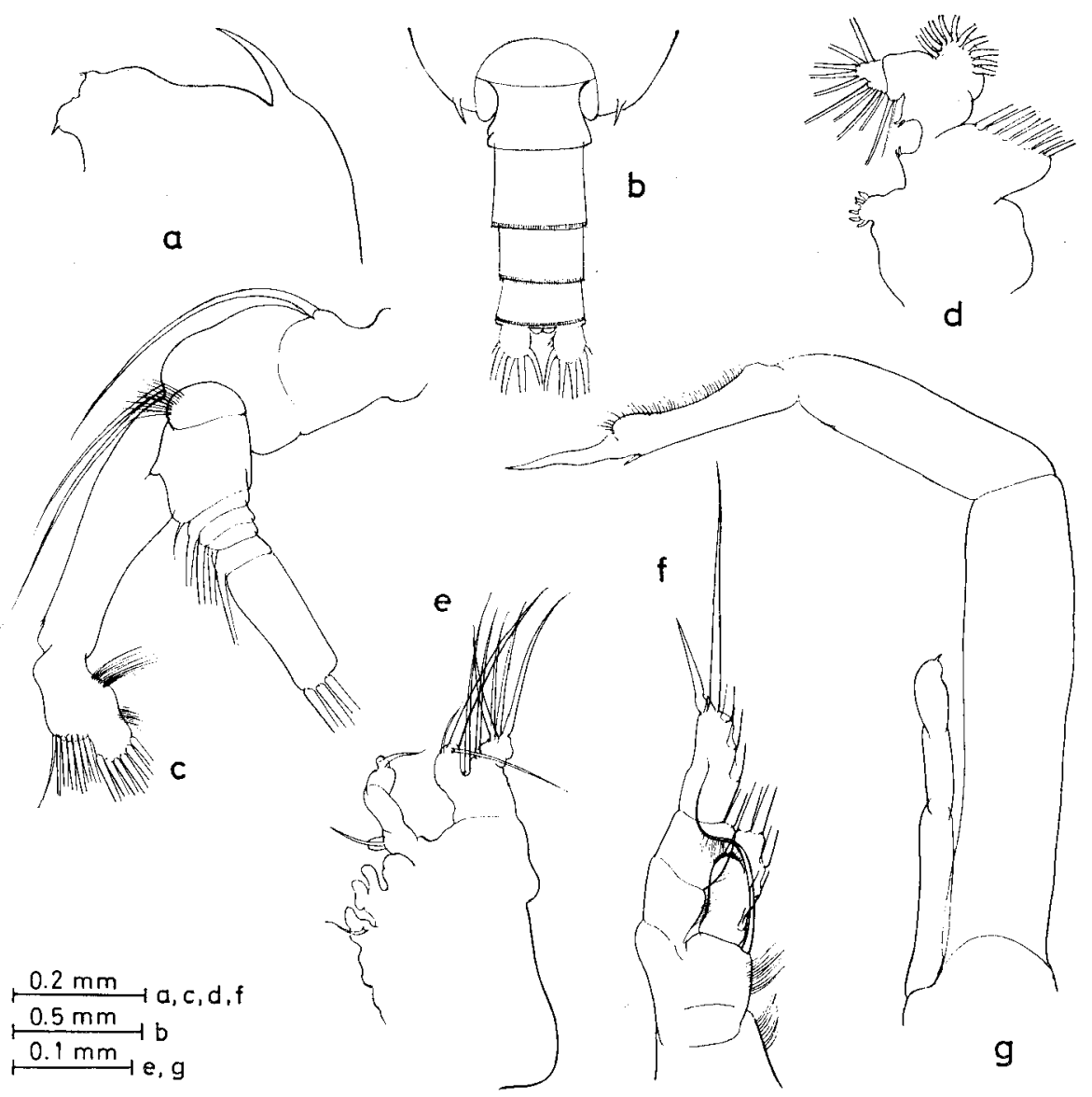

Fig. 10. Gaetanus kruppii Giesbrecht, male: a, head, lateral view; b, last thoracic segment and abdomen, dorsal view; c, 2nd antenna; d, 1st maxilla; e, 2nd maxilla; f, 1st leg; $\mathrm{g}$, distal part of left 5 th leg.

The 1st antenna exceeds the end of furca by 2 segments; the segments are in the following proportional lengths:

\begin{tabular}{lrrrrrrrrrrrrr} 
segment & 1 & 2 & 3 & 4 & 5 & 6 & 7 & $8-9-10$ & 11 & $12-13$ & 14 & 15 & 16 \\
\cline { 2 - 3 } & 70 & 32 & 24 & 22 & 28 & 28 & 30 & 72 & 26 & 47 & 24 & 47 & 51
\end{tabular}

\begin{tabular}{rrrrrrr}
17 & 18 & 19 & $20-21$ & 22 & 23 & $24-25$ \\
\hline 47 & 56 & 70 & 130 & 74 & 66 & 56
\end{tabular}$=1000$

The proximal 8 segments are provided with long sensory filaments.

In the 2nd antenna the endopod is a little longer than the exopod; the endopod carries 6 setae on the outer lobe and 7 setae on the inner lobe. The mandibular 
palp bears a single short seta; the endopod has 9 setae on the distal margin. The 1st maxilla has 7 long setae on the outer lobe, 10 setae on the exopod, 9 setae on the endopod, and 2 setae on the 2 nd basal segment; the 1 st to 3 rd inner lobes are considerably reduced. The 2nd maxilla is reduced; the endopod has 6 setae; the 1 st to 5 th lobes are quite deformed. The maxilliped is of the usual structure; the 2nd basal segment is longer than the 1st one.

In the 1 st leg the exopod is incompletely 3-segmented: there is no marginal spines on the 1 st and 2nd segment of the exopod. The 2nd leg has a 3-segmented exopod and 2-segmented endopod. The 3rd and 4th legs each have a 3-segmented exopod and endopod. The terminal spine of the exopod of the 4 th leg has 27 teeth. In the left 5 th leg the 3 rd segment of the exopod has scattered hairs on the outer margin; the endopod is incompletely 3 -segmented, and extends seven-tenths the length of the 1st segment of the exopod; the apex of the endopod has a small spine.

Remarks: The female specimens agree quite well with the description given by previous authors. The lamella of the maxilliped is in complete accordance with that described by WITH (1915). The 4th leg has 22 tube-like spinules on the inner margin of the 1st basal segment. On the other hand, the male specimens differ from those described by previous authors in the structure of the left 5th leg. According to $\mathrm{W}_{\mathrm{ITH}}$ (1915) and SEwELL (1947) the 2nd segment of the exopod has several small processes on the outer distal margin. However, these processes are absent in the present specimens. The distal segment of WITH's or Sewell's specimens is long and simple in structure, but this segment in the present specimens is inflated at the base of the terminal spine, and has scattered hairs on the outer margin. The 1st and 2nd maxillae figured by SEwell (1947) differ from those of the present male specimens in details of the structure. It is not yet definite if these characters observed in the present specimens represent a Pacific Ocean form.

\section{Distribution and size variations:}

\begin{tabular}{|c|c|c|c|c|}
\hline \multirow[t]{2}{*}{ Author } & \multirow[t]{2}{*}{ Locality } & \multirow[t]{2}{*}{ Depth $(\mathrm{m})$} & \multicolumn{2}{|c|}{ Length (mm) } \\
\hline & & & ㅇ & $\hat{\jmath}$ \\
\hline WOLFENDEN, 1904 & Faröe Channel & 550 & $<5.0$ & 4.65 \\
\hline A. Sсотт, 1909 & Malay Archipelago & $0-1500$ & 5.70 & 5.60 \\
\hline WITH, 1915 & North Atlantic & $0-600$ & 5.40 & 5.04 \\
\hline SARS, 1925 & Atlantic & $0-3000$ & 5.2 & - \\
\hline FARRAN, 1926 & Bay of Biscay & $640-1000$ & $4.45-4.80$ & - \\
\hline SEWELL, 1947 & Arabian Sea & $0-1500$ & - & 5.17 \\
\hline TANAKa, $1957 \mathrm{~b}$ & Izu region & $0-1000$ & 4.95 & 4.87 \\
\hline VERVOORT, 1963 & Gulf of Guinea & $0-600$ & $4.70-5.60$ & $4.20-4.40$ \\
\hline Present record & Izu region & $0-970$ & $4.70-5.30$ & $4.50-4.90$ \\
\hline
\end{tabular}




\section{Gaetanus latifrons SARS, 1905}

(Fig. 11, a-d)

Gaetanus latifrons SARs, 1905, p. 11; A. SCOTt, 1909, p. 49, pl. 10, figs. 10-17; SARs, 1925, p. 57, pl. 17, figs. 7-9.

Gaetanus holti FArran, 1905, p. 33, pl. 6, figs. 1-12.

Gaetanus paracurvicornis BRoDSKY, 1950, p. 167, fig. 84 .

Occurrence: Sta. 115-1, 19; Sta. 120, 1 우.

Descriptive notes: Female, $4.75 \mathrm{~mm}$. The cephalothorax and abdomen are in the proportional lengths 79:21. The cephalic spine is of characteristic shape. The abdominal segments and furca are in the following proportional lengths: segment

\begin{tabular}{rrrrr}
$1-2$ & 3 & 4 & 5 & furca \\
\hline 37 & 15 & 15 & 14 & 19
\end{tabular}$=100$

The 1st antenna exceeds the end of furca by 3 segments; the segments have the following proportional lengths:

\begin{tabular}{lrrrrrrrrrrrrrr} 
segment & 1 & 2 & 3 & 4 & 5 & 6 & 7 & $8-9$ & 10 & 11 & 12 & 13 & 14 & 15 \\
\cline { 2 - 11 } & 69 & 32 & 21 & 19 & 23 & 24 & 24 & 47 & 23 & 26 & 28 & 55 & 53 & 53
\end{tabular}

\begin{tabular}{llllllllll}
16 & 17 & 18 & 19 & 20 & 21 & 22 & 23 & 24 & 25 \\
\hline 49 & 49 & 51 & 60 & 60 & 49 & 60 & 53 & 51 & 21
\end{tabular}$=1000$

In the 2nd antenna the exopod is slightly longer than the endopod; the endopod carries 7 setae on the outer lobe, and 8 setae on the inner lobe. The 1st maxilla has 8 setae on the outer lobe, 11 setae on the exopod, $7+4+4$ setae on the 3 rd to 1 st segments of the endopod, 5 setae on the 2nd basal segment, 4 setae on the 3rd inner lobe, 5 setae on the 2 nd inner lobe, and 13 setae on the 1 st inner lobe. The maxilliped has a slender lamella on the 1st basal segment.

The 1st leg has a 3-segmented exopod and 1-segmented endopod; the 1st segment of the exopod has a marginal spine. In the left 4 th leg the 1 st basal segment bears 21 spinules on the inner margin, whereas it bears 19 spinules in the right leg.

Remarks: The species appears to be distributed widely in the deep waters of the Atlantic, Indian, and Pacific Oceans. The Atlantic Ocean form of G. latifrons is well-described by VERVOort (1952b). The Pacific Ocean form seems to differ somewhat from the Atlantic Ocean form in the shape of the forehead and in having long 1st antenna which extends beyond the furca by at least 3 segments. The present specimens agree quite well in these aspects with the description and figures of the Siboga specimen obtained from the Malay Archipelago (A. Sсотт, 1909). BRodsky (1950) proposed a new species, G. paracurvicornis, for the present Pacific form. In our opinion, the characters given are insufficient for a distinct species, but there is a possibility to establish a new sub-species for the Pacific Ocean form. This is the first record of occurrence in Japanese waters. 


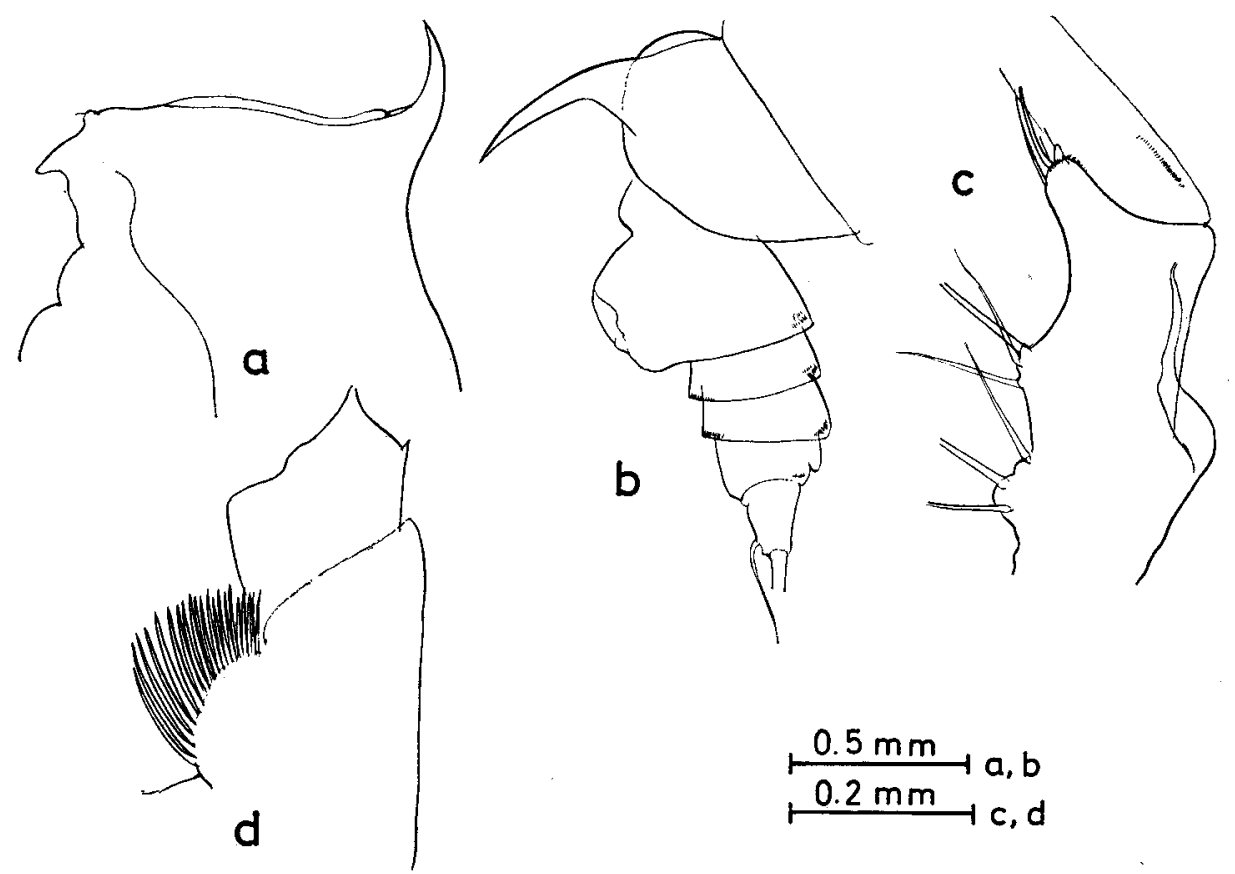

Fig. 11. Gaetanus latifrons SARs, female: a, head, lateral view; b, last thoracic segment and abdomen, lateral view: $c$, 1st basal segment of maxilliped; d, 1st basal segment of left 4th leg.

Distribution and size variation:

\begin{tabular}{|c|c|c|c|c|}
\hline \multirow[t]{2}{*}{ Author } & \multirow[t]{2}{*}{ Locality } & \multirow[t]{2}{*}{ Depth $(\mathrm{m})$} & \multicolumn{2}{|c|}{ Length (mm) } \\
\hline & & & q & $\hat{\sigma}$ \\
\hline FARRAN, 1905 & Irish Atlantic Slope & $600-2100$ & 5.1 & - \\
\hline А. Sсотт, 1909 & Malay Archipelago & $0-750$ & 5.4 & - \\
\hline $\mathrm{W}_{\mathrm{ITH}}, 1915$ & North Atlantic & $0-600$ & 5.1 & - \\
\hline SARS, 1925 & North Atlantic & $0-4500$ & 5.0 & - \\
\hline FARRAN, 1926 & Bay of Biscay & $641-915$ & 4.8 & - \\
\hline Seweil, 1947 & Arabian Sea. & $0-500$ & - & - \\
\hline BroDSKY, 1950 & Northwestern Pacific & $1000-4000$ & 4.6 (juv.) & 4.1 (juv.) \\
\hline VERVOORT, 1957 & South of Tasmania & $500-750$ & - & - \\
\hline VERVOORT, 1963 & Gulf of Guinea & $0-600$ & $4.65-5.20$ & - \\
\hline Present record & Izu region & $0-921$ & $4.60,4.75$ & - \\
\hline
\end{tabular}

\section{Gaetanus miles GIESBREChT, 1888}

Gaetanus miles GiesBRecht, 1888, p. 335; GiesBrecht, 1892, p. 219, pl. 14, figs. 21, 24, 25, 27, 30, pl. 30, figs. 1, 3; A. Scott, 1909, p. 44, pl. 8, figs. 1-8; TANAKA, 1957b, p. 174, fig. 42 h-1; Grice, 1962, p. 192, pl. 8, figs. 8-13. 
Occurrence: Sta. 108, 1 ; ; Sta. 109, 1; Sta. 115-2, 1 ㅇ. Distribution and size variation:

\begin{tabular}{|c|c|c|c|c|}
\hline \multirow[t]{2}{*}{ Author } & \multirow[t]{2}{*}{ Locality } & \multirow[t]{2}{*}{ Depth $(\mathrm{m})$} & \multicolumn{2}{|c|}{ Length $(\mathrm{mm})$} \\
\hline & & & q & $\sigma^{*}$ \\
\hline Giesbreaht, 1888 & Pacific & $0-1800$ & 3.50 & - \\
\hline А. Sсотт, 1909 & Malay Archipelago & $0-2000$ & 4.30 & - \\
\hline WOLFENDEN, 1911 & South Atlantic & $0-3000$ & ca. 3.0 & - \\
\hline WITH, 1915 & North Atlantic & $0-600$ & 4.21 & - \\
\hline SARS, 1925 & Atlantic & $0-3000$ & 3.90 & - \\
\hline FARRAN, 1926 & Bay of Biscay & $275-366$ & 4.25 & - \\
\hline TANAKA, $1957 \mathrm{~b}$ & Sagami Bay & $0-1000$ & 3.96 & - \\
\hline GRIGE, 1962 & Equatorial Pacific & & $3.40-3.52$ & - \\
\hline VERVOORT, 1963 & Gulf of Guinea & $0-\quad 10$ & 3.20 (juv.) & 3.00 (juv.) \\
\hline Present record & Izu region & $0-680$ & $4.20-4.40$ & - \\
\hline
\end{tabular}

Gaetanus minispinus Tanaka, 1969

Gaetanus minispinus TanaKa, 1969, p. 260, fig. 4.

Occurrence: Sta. 109, 1 ; Sta. 111-1, 1 ; Sta. 116, 1q; Sta. 121-2, 1 q

Remarks: Gaetanus minispinus is closely allied to G. kruppii but is easily distinguished from the latter in having a very small cephalic spine. The species was first found in the Albatross collection deposited in the U.S. National Museum, among specimens labelled "Euchirella galeata Giesbrecht". The male is unknown.

Distribution and size variation:

$\begin{array}{llll}\text { Author } & \text { Locality } & \text { Depth }(\mathrm{m}) & \begin{array}{c}\text { Length }(\mathrm{mm}) \\ \frac{9}{+}\end{array} \\ \text { TANAKA, 1969 } & \text { Bashi Channel } & 0-915 & 5.50 \\ \text { Present record } & \text { Izu region } & 0-680 & 5.15-5.56\end{array}$

\section{Gaetanus minor FARRAN, 1905}

Gaetanus minor Farran, 1905, p. 34, pl. 5, figs. 1-11; A. ScotT, 1909, p. 47, pl. 9, figs. 1-8; TAnaka, 1957b, p. 172, fig. 42 e-g.

Occurrence: Sta. 94-1, 3; Sta. 96, 2q; Sta. 97-2, 1\%; Sta. 108, 1 $\%$; Sta. 115-1, 2\%; Sta. 115-2, 2क; Sta. 117-1, 2q; Sta. 119, 1 q.

Distribution and size variation:

\begin{tabular}{llccc} 
Author & Locality & Depth $(\mathrm{m})$ & Length $(\mathrm{mm})$ \\
& & & + & \multicolumn{1}{c}{} \\
FARRAN, 1908 & Irish Atlantic Slope & $730-1830$ & 2.40 & -
\end{tabular}




$\begin{array}{llcll}\text { A. ScotT, 1909 } & \text { Malay Archipelago } & 0-1500 & 2.30 & - \\ \text { Wolfenden, 1911 } & \text { South Atlantic } & 0-1500 & 1.75-2.00 & - \\ \text { With, 1915 } & \text { Atlantic } & 0-100 & 2.30 & - \\ \text { SARS, 1925 } & \text { Atlantic } & 0-2000 & 2.10 & - \\ \text { FARRAN, 1929 } & \text { Off New Zealand } & 0 & 2.16 & - \\ \text { FARRAN, 1936 } & \text { Great Barrier Reef } & 0-600 & 2.1 & - \\ \text { BrodSkY, 1948 } & \text { Sea of Japan } & 1000-2000 & 2.1-2.4 & - \\ \text { VeRVoORT, 1957 } & \text { Malay Archipelago } & 0-800 & 2.10 & - \\ \text { TANAKA, 1957b } & \text { Sagami Bay } & 0-1000 & 2.23 & - \\ \text { DE PAIVA, 1963 } & \text { Off Cape Verde Is. } & - & 2.23-2.26 & - \\ \text { Present record } & \text { Izu region } & 0-360 & 2.10-2.30 & -\end{array}$

\section{Gaetanus pileatus FARRAN, 1903}

Gaetanus pileatus FArran, 1903, p. 16, pl. 17, figs. 1-11; SARs, 1925, p. 56, pl. 17, figs. 3-6; Tanaka, $1957 \mathrm{~b}$, p. 175 , fig. 43.

Gaetanus caudani Wolfenden, 1904, p. 114, pl. 9, figs. 20-22.

Occurrence: Sta. 108, 1 ; Sta. 114, 1q; Sta. 115-2, 1q; Sta. 117-1, 1\%; Sta. 122,1 ㅇ.

Distribution and size variation:

\begin{tabular}{|c|c|c|c|c|}
\hline \multirow[t]{2}{*}{ Author } & \multirow[t]{2}{*}{ Locality } & \multirow[t]{2}{*}{ Depth $(\mathrm{m})$} & \multicolumn{2}{|c|}{ Length (mm) } \\
\hline & & & 우 & $\delta$ \\
\hline WOLFENDEN, 1904 & North Atlantic & $0-1100$ & $<5.00$ & - \\
\hline A. Scotr, 1909 & Malay Archipelago & $0-2000$ & 6.0 & - \\
\hline WITH, 1915 & North Atlantic & $0-600$ & 5.74 & - \\
\hline SARS, 1925 & Atlantic & $0-500$ & 6.20 & 4.70 \\
\hline FARRAN, 1926 & Bay of Biscay & $366-1370$ & $5.3-5.4$ & - \\
\hline Sewell, 1929 & Bay of Bengal & $0-366$ & 4.1 & - \\
\hline SEWELL, 1947 & Arabian Sea & $400-645$ & - & - \\
\hline WiLsON, 1950 & Off Peru & $0-550$ & - & - \\
\hline TANAKA, $1957 \mathrm{~b}$ & Sagami Bay & $0-1000$ & 6.14 & - \\
\hline VERVOORT, 1963 & Gulf of Gruinea & $0-600$ & $5.95-6.10$ & $4.80-5.30$ \\
\hline $\begin{array}{l}\text { OWre and } \\
\text { Foyo, } 1967\end{array}$ & Florida Current & 171 & $5.0-5.3$ & - \\
\hline Present record & Izu region & $0-900$ & $5.50-6.00$ & - \\
\hline
\end{tabular}

(To be continued) 